\title{
Kuwait: Financial System Stability Assessment, including Reports on the Observance of Standards and Codes on the following topics: Banking Supervision, Securities Regulation, Anti-Money Laundering and Combating the Financing of Terrorism
}

This Financial System Stability Assessment on Kuwait was prepared by a staff team of the International Monetary Fund and the World Bank as background documentation for the periodic consultation with the member country. It is based on the information available at the time it was completed on January 20, 2004. The views expressed in this document are those of the staff team and do not necessarily reflect the views of the government of Kuwait or the Executive Board of the IMF.

The policy of publication of staff reports and other documents by the IMF allows for the deletion of market-sensitive information.

To assist the IMF in evaluating the publication policy, reader comments are invited and may be sent by e-mail to publicationpolicy@imf.org.

Copies of this report are available to the public from

International Monetary Fund $\bullet$ Publication Services

700 19th Street, N.W. • Washington, D.C. 20431

Telephone: (202) 6237430 • Telefax: (202) 6237201

E-mail: publications@imf.org • Internet: http://www.imf.org

Price: $\$ 15.00$ a copy

\section{International Monetary Fund} Washington, D.C. 



\title{
INTERNATIONAL MONETARY FUND
}

\author{
KUWAIT \\ Financial System Stability Assessment \\ Prepared by the Monetary and Financial Systems and Middle East
and Central Asia Departments
}

Approved by Stefan Ingves and George Abed

January 20, 2004

This Financial System Stability Assessment (FSSA) report is based primarily on work undertaken during a visit to Kuwait in September 2003, as part of the Financial Sector Assessment Program (FSAP). The FSAP findings were discussed further with the authorities during the Article IV consultation mission in October 2003.

The FSAP team comprised Karl Habermeier (Head, MFD); Samir El Daher (Deputy Head, World Bank); George Iden, Alessandro Giustiniani, and Richard Chalmers (all MFD); Ibrahim Al Gelaiqah (MCD); Joy Smallwood (LEG); Tadashi Endo, Deane Jordan, Peter Kyle, and Richard Zechter (all World Bank); James Dingle (formerly Bank of Canada); Ashraf Shamseldin (formerly Egypt Capital Market Authority); and Michael Yuenger (U.S. OCC).

The core of Kuwait's financial system is the banking sector. The securities sector is also large and active, while the insurance sector is small. Banking regulation and supervision are broadly in line with international standards, but the legal and regulatory frameworks for other parts of the financial system need to be further developed.

Banks are well-capitalized and liquid and can withstand considerable shocks, although some may be more sensitive than others to large shocks to the equities and real estate markets. Financial system stability has been supported by sound macroeconomic policies, but continued vigilance is needed to avoid a repetition of earlier government bailouts.

The FSAP team conducted assessments of three international standards and codes: the Basel Core Principles for Effective Banking Supervision; the Objectives and Principles of Securities Regulation; and the Anti-Money Laundering and Combating the Financing of Terrorism Standards. Reports on the Observance of Standards and Codes (ROSCs) summarizing these standards assessments are contained in an appendix to this report and underpin its analysis and recommendations.

FSAPs are designed to assess the stability of the financial system as a whole and not that of individual institutions. They have been developed to help countries identify and remedy weaknesses in their financial sector structure, thereby enhancing their resilience to macroeconomic shocks and cross-border contagion. FSAPs do not cover risks that are specific to individual institutions such as asset quality, operational or legal risks, or fraud. 


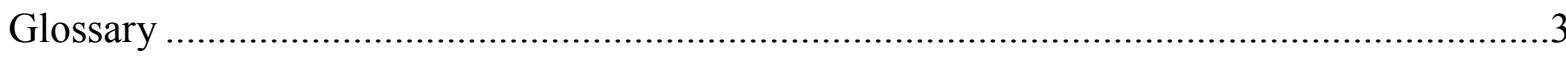

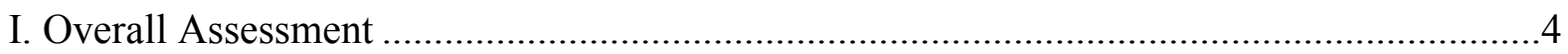

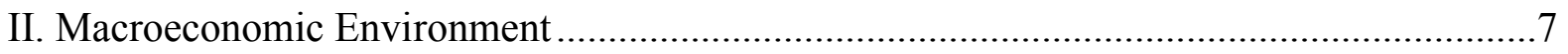

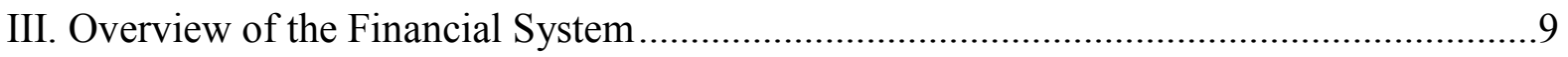

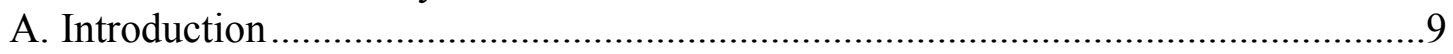

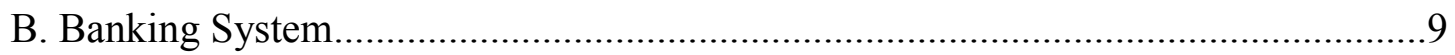

C. Non-Bank Financial Institutions .....................................................................11

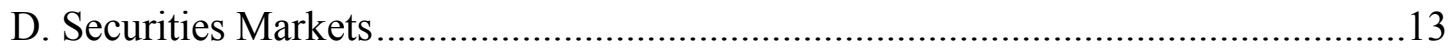

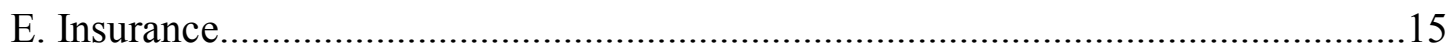

F. Anti-Money Laundering/Combating the Financing of Terrorism ............................15

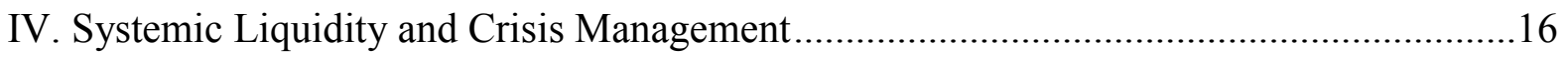

A. Monetary Instruments and Operations …………………...................................16

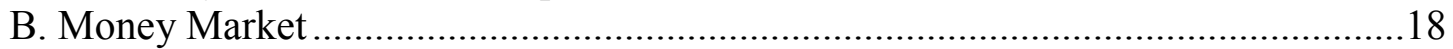

C. Payment System .............................................................................................

D. Lender of Last Resort and Deposit Insurance .....................................................19

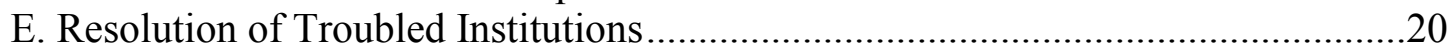

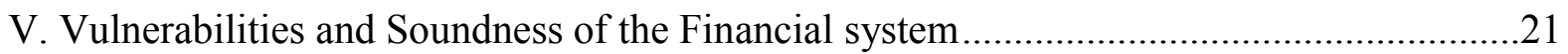

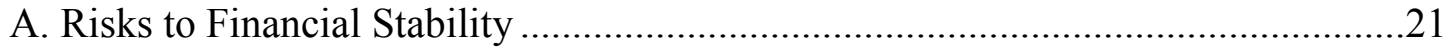

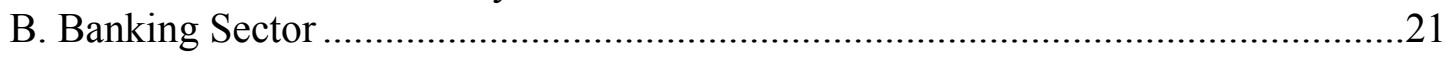

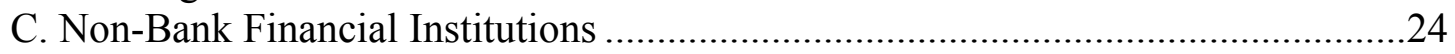

VI. Key Structural Issues Affecting Financial Stability ………..........................................2.

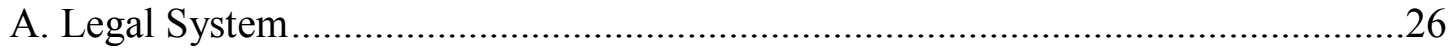

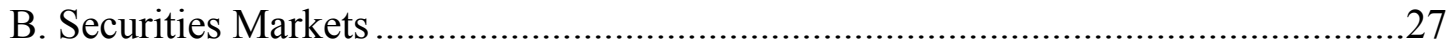

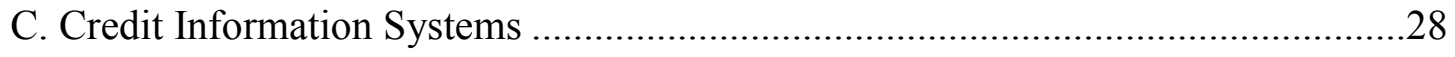

Text Tables

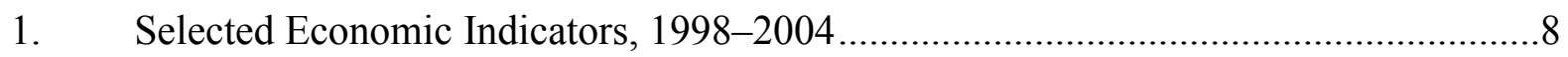

2. Financial System Structure, 1998-2003 ……….................................................

3. Financial Soundness Indicators for the Banking Sector, 1999-2003 …....................22

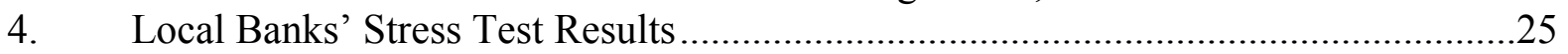

\section{Boxes}

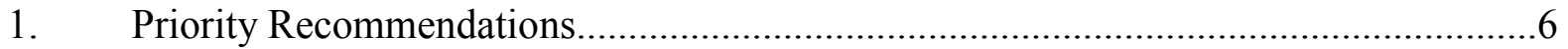

2. Regulation and Supervision of Islamic Financial Institutions .....................................11

Appendices

I. Summary Assessment of Compliance of the Basel Core Principles for Effective

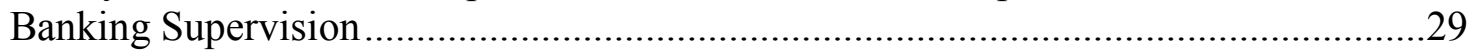

II. IOSCO Objectives and Principles of Securities Regulation ................................................35

III. Report on Observance of Standards and Codes FATF Recommendations for Anti-Money Laundering and Combating the Financing of Terrorism. 


\section{GlosSARY}

$\begin{array}{ll}\text { AML } & \text { Anti-money laundering } \\ \text { BCP } & \text { Basel Core Principles on Effective Banking Supervision } \\ \text { CAR } & \text { Capital adequacy ratio } \\ \text { CBK } & \text { Central Bank of Kuwait } \\ \text { CD } & \text { Company Department, Ministry of Commerce and Industry } \\ \text { CFT } & \text { Combating the financing of terrorism } \\ \text { CIS } & \text { Collective investment scheme } \\ \text { DI } & \text { Department of Insurance, Ministry of Commerce and Industry } \\ \text { DVP } & \text { Delivery versus payment } \\ \text { FATF } & \text { Financial Action Task Force } \\ \text { FIU } & \text { Financial intelligence unit } \\ \text { FSAP } & \text { Financial Sector Assessment Program } \\ \text { GCC } & \text { Gulf Cooperation Council } \\ \text { IAIS } & \text { International Association of Insurance Supervisors } \\ \text { IAS } & \text { International Accounting Standards } \\ \text { IOSCO } & \text { International Organization of Securities Commissions } \\ \text { KATS } & \text { Kuwait Automated Trading System } \\ \text { KCC } & \text { Kuwait Clearing Company } \\ \text { KSE } & \text { Kuwait Stock Exchange } \\ \text { MC } & \text { Market Committee } \\ \text { MoCI } & \text { Ministry of Commerce and Industry } \\ \text { MoFE } & \text { Ministry of Finance and Economy } \\ \text { MOU } & \text { Memorandum of understanding } \\ \text { NPL } & \text { Nonperforming loan } \\ \text { OPEC } & \text { Organization of Petroleum Exporting Countries } \\ \text { PAHW } & \text { Public Authority for Housing Welfare } \\ \text { POS } & \text { Point of sale } \\ \text { PPO } & \text { Public Prosecutor's Office } \\ \text { RTGS } & \text { Real time gross settlement } \\ \text { SC } & \text { Special clearing } \\ \text { SME } & \text { Small- and medium-sized enterprises } \\ \text { STR } & \text { Suspicious transaction report } \\ & \\ \text { MOE }\end{array}$




\section{Overall AsSessment}

1. The authorities have succeeded in maintaining financial system stability in a difficult environment. Despite large fluctuations in oil prices, regional security threats, large swings in the local equities market, and the moral hazard and rent seeking that great wealth can engender, the authorities have successfully used regulation and supervision to safeguard the stability of the banks, which are at the core of the financial system. However, vigorous regulatory and institutional reform, especially in the securities sector, is desirable in the interest of continued stability and greater efficiency. Although Kuwait possesses sufficient wealth to offset even a major financial crisis without any effect on present levels of consumption, policies should be geared to avoiding the waste of resources and burden on future generations that such an eventuality would entail.

\section{Financial stability has been effectively supported by prudent fiscal and monetary} policies. Together with an open and free exchange and trade system, these policies have kept inflation low and domestic incomes stable despite wide fluctuations in global oil prices. The objective of building up official assets to allow future generations to benefit from oil wealth is also conducive to stability, although the escalating burden of the social welfare system, government employment policies in the face of rapid population growth, and greater international integration call for wide-ranging structural reforms, in the financial sector and beyond, if stability is to be maintained in the longer run.

3. The banking sector appears sound and is well-regulated and supervised. Capitalization, asset quality, earnings, and liquidity are all strong; and the major institutions offer a wide variety of up-to-date banking products and services. The CBK has established a comprehensive system for banking regulation and supervision that conforms in most respects to international standards. It would be desirable to adopt amendments to the CBK Law that further enhance the powers and independence of the CBK in its capacity as banking regulator and supervisor, and firmly establish its ability to effectively conduct consolidated supervision.

\section{Stress tests indicate that the banking system could withstand significant shocks.} Sensitivity to market risk is limited owing to the short-maturity structure of interest bearing instruments, while exchange rate risk has been contained by strict enforcement of prudential requirements. Liquidity is adequate, and Kuwait's large foreign reserves allow for the provision, if necessary, of ample lender-of-last resort support in both domestic and foreign currency. Most banks appear able to absorb a fairly pronounced deterioration in asset quality. However, some institutions show a particular sensitivity to price declines in the equity and property markets, although overall the exposure of the banking system to these risks appears to be manageable. Even so, these exposures should be carefully monitored by supervisors; and the banks concerned should be required to take action to reduce their vulnerability.

5. The equities market is among the largest and most active in the Arab world, but it has historically shown large swings, and exhibits weak governance structures. Equity prices have once again increased markedly over the last year and reached new record highs. Regulation and supervision exhibit significant gaps and are scattered among a multiplicity of laws and agencies. The creation of a single, independent, and accountable capital market regulatory agency is a high priority, to address the risks associated with inadequately regulated market activities. Insider trading 
and market manipulation should be proscribed, and international auditing and disclosure standards should be enforced.

6. The insurance sector is small, its development is constrained by economic and social policies, and there is significant room for improvement in its regulation and supervision. The predominant role of the government in the economy limits the market for non-life insurance, while the generous social welfare system has dampened the demand for private life and health insurance. Regulators have limited entry; and domestic insurance companies rely heavily on reinsurance, acting mainly as brokers rather than underwriters. Regulation and supervision are based on an old law that is missing many of the key elements of a modern insurance supervision regime. A revised legal framework that includes the creation of an independent supervisory agency and the upgrading of supervisory capacity are high priorities.

7. Kuwait's regulatory and supervisory framework for AML/CFT has recently been strengthened, including through enactment of new legislation. However, significant vulnerabilities exist in the AML/CFT systems, and early action should be taken to address these.

\section{Monetary operations have been effective in achieving policy objectives, but their} efficiency could be enhanced in some respects. The CBK relies on both market-based and administrative instruments of monetary policy. Its most actively used instrument is a deposit auction, but it also imposes liquidity ratios that bind the bulk of government securities and preclude the development of repurchase operations. Consideration could be given to developing marketable instruments for use in open market operations and to support the development of a secondary market. The CBK also imposes a ceiling on lending rates, which should be eased or removed. More generally, a streamlining of the framework for monetary operations could be considered. The development and implementation of monetary policy are broadly transparent.

9. Other vital aspects of systemic liquidity and crisis management policies are broadly in place, but some of these could be strengthened. The CBK has the authority to engage in emergency lending, based on collateral it considers adequate, but it has not needed to use this authority in recent years. There are plans to lift the implicit blanket guarantee on bank deposits, accompanied by steps to avoid liquidity problems. The CBK has decided against coupling the lifting of the guarantee with the establishment of a formal deposit insurance scheme, owing to the preponderance of large deposits in the banking system. However, this approach leaves open the actions to be taken if a bank run should ever develop. Introducing coverage for small deposits on social policy grounds remains an option, especially given the large number of small depositors whose aggregate holdings account for a small share of the total. The CBK has a variety of powers to deal with problem banks, although it would be desirable to also provide it with the sole power to revoke banking licenses and arrange bank mergers, which presently require the approval of the minister of finance. 


\section{Box 1. Priority Recommendations}

- General. Take steps to reduce moral hazard and encourage economic agents to deal prudently with risk, including through the elimination of the blanket deposit guarantee, bank bailouts, and bailouts of investors in the stock and real estate markets.

- Banking. (i) enact amendments to the CBK law that enhance the independence and powers of the CBK in its capacity as banking regulator and supervisor, to firmly establish its ability to conduct consolidated supervision and take remedial measures; (ii) continue to closely monitor banks' lending risk associated with the stock market and real estate sectors, and further develop related stress testing procedures and capabilities within the banking supervision department, and be prepared to take quick supervisory action if necessary; (iii) ease or remove the ceiling on lending rates, to enable lenders to better price the risks of lending, including in particular to SMEs; and (iv) seek authority to share confidential information for supervisory purposes with appropriate domestic and foreign authorities.

- $\quad$ Securities. (i) enact a new Capital Markets Law creating a single, independent and accountable authority with full powers to develop and regulate the securities market and industry; (ii) prohibit insider trading and market manipulation, and enforce by establishing comprehensive inspection, investigation and surveillance systems; (iii) define entry standards for all types of market intermediaries; (iv) develop unified code of prudential regulations; and (v) allow the market to diversify product lines, and liberalize participation of foreign intermediaries in the market.

- Insurance. (i) enact a new insurance law that includes the elements of a modern insurance supervision framework, including independent status for the supervisory agency; (ii) strengthen the capacity of the insurance department of the MoCI in the near term.

- $\quad$ AML/CFT. (i) formally extend Law 35/2002 to cover the broad financial sector; (ii) exercise more control over ownership of financial institutions; (iii) strengthen procedures for international cooperation in $\mathrm{AML} / \mathrm{CFT}$; and (iv) criminalize the financing of terrorism.

- Monetary operations. (i) in liquidity management, reduce reliance on banks' deposits with CBK by using marketable instruments in monetary operations; (ii) simplify and streamline the multiple liquid asset requirements, and in the medium term, reduce or introduce more flexibility in the 20 percent liquid asset requirement (e.g., counting deposits with the CBK and permitting banks to meet the requirement on average over a period of time rather than every day); and (iii) building on the preceding steps, foster secondary market development.

- Payment system. Continue high priority implementation of the RTGS system, ensuring that its regulations comply with Core Principles 3 (management of credit risks and liquidity risks) and 9 (objective and publicly disclosed criteria for participation, and in general publicly disclosing major policies). 


\section{MACROECONOMIC ENVIRONMENT}

10. Over the past decade, Kuwait has made an impressive recovery from the economic damage caused by the 1990-91 war. Oil production and exports have been restored, and fiscal and external current account balances since the mid-1990s have reached surpluses on the order of 20 percent of GDP. ${ }^{1}$ The stock of foreign assets has recovered; the country's infrastructure has been rebuilt; and public debt has been substantially reduced. Inflation, which in the first years after the war averaged 10 percent a year, has fallen to about 2 percent a year since the late 1990s. Economic activity continues to be highly dependent on oil; and the government sector dominates most economic activities, including oil, transportation, telecommunications, utilities, and financial services (with strong linkages between the ruling family, the government, and the financial sector). ${ }^{2}$

11. In 2002-03, reflecting mainly higher oil prices, the fiscal surplus (including investment income) is estimated at 25 percent of GDP. The external current account surplus is estimated to have moderated to a still robust 12 percent of GDP in 2002 (Table 1). Net foreign assets of the CBK declined to the equivalent of about eight months of prospective imports of goods and services. Growth of broad money slowed to 5 percent in 2002 from 13 percent in 2001, despite a strong pickup in credit to the private sector in response to low interest rates - most of the increase financed personal loans to consumers, real estate lending, securities trading, and loans to nonbank financial institutions, with limited impact on the growth of non-oil GDP. Real GDP is estimated to have decreased by about 1 percent in 2002, owing mainly to a drop in oil production in line with OPEC mandates. Non-oil GDP growth remained sluggish, reflecting the cuts in government capital expenditure and private sector caution in the face of delays in structural reform and regional uncertainties.

12. Economic performance in $\mathbf{2 0 0 3}$ appears to have benefited from the war in Iraq, primarily via higher oil prices and production, and an expansion in domestic non-oil activity. For the year as a whole, real GDP is estimated to have increased by 10 percent. The financial position in 2003 appears to have remained favorable, with both external current account and fiscal surpluses at 19 percent of GDP. The medium-term outlook, under current policies, is for modest GDP growth with large fiscal and external current account surpluses, but the economy will continue to be affected by regional political developments and fluctuations in oil prices.

\footnotetext{
${ }^{1}$ Fund staff estimates of the overall fiscal balance differs from official data because they include investment income of government foreign assets.

${ }^{2}$ According to the ministry of planning, the government sector constituted 71 percent of GDP in 2002.
} 
Table 1. Kuwait: Selected Economic Indicators, 1998-2004

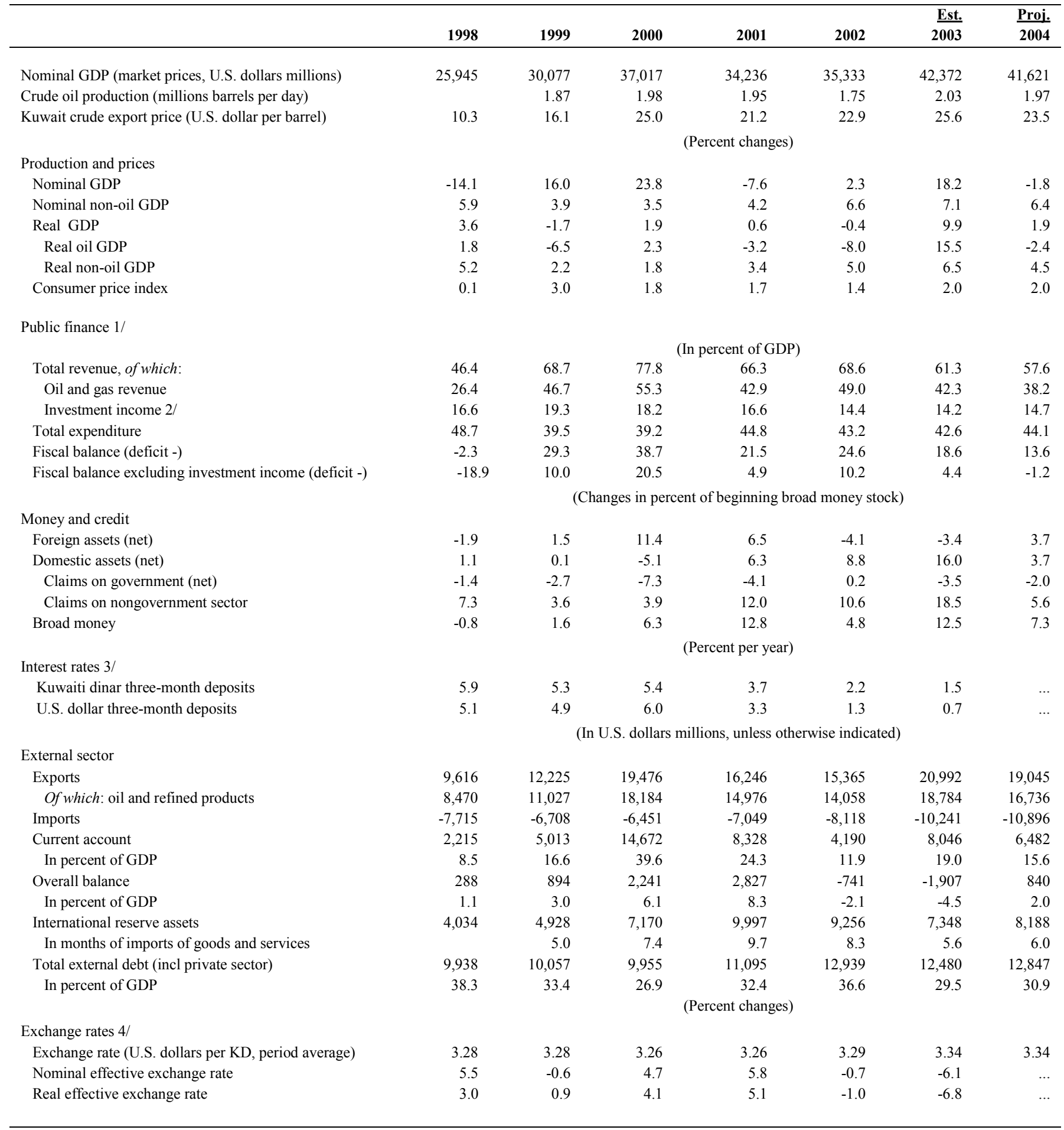

Sources: Data provided by the authorities; and staff estimates.

$1 /$ The fiscal numbers are for fiscal year which was changed from July-June to April-March effective 2001/02.

2/ Includes profit of public enterprises.

3/ In 2003, up to end September.

4/ In 2003, up to end August. 
13. In the years ahead, the Kuwaiti authorities will face difficult decisions. Kuwait's fiscal policy reflects the objective of building up official assets so that future generations might benefit from the proceeds of the nonrenewable oil reserves. ${ }^{3}$ However, fiscal developments still remain heavily dependent on oil revenues, while the escalating burden of the social welfare system calls for a reform in its structure. ${ }^{4}$ Reducing unemployment will require choices between increased government consumption and investment. The planned monetary union among GCC countries will pose further challenges, including the coordination of fiscal policies and external competitiveness. ${ }^{5}$

\section{OVERVIEW OF THE FinANCIAL SYSTEM}

\section{A. Introduction}

14. The Kuwaiti financial system is sizeable and well developed. Besides commercial and specialized banks at the core of the system, it includes a growing number of financial companies and investment funds, as well as insurance companies and an active stock exchange. At the end of 2002, total assets of financial institutions amounted to more than 200 percent of GDP, while stock market capitalization reached about 100 percent of GDP (Table 2). Although the establishment of new banks domestically is restricted, there is adequate competition in financial markets, with the exception of the insurance sector. Domestic institutions offer a wide range of up-to-date services.

\section{B. Banking System}

\section{The banking sector comprises a limited number of institutions, mostly privately owned,} and concentration is high. Of the seven commercial banks, one operates under Islamic law, two are specialized banks focusing on industry and real estate, and one is a branch of a foreign bank. Though the government directly or indirectly holds controlling interests in two banks, most are privately owned and usually controlled by a related group of shareholders. Only one bank has diffuse ownership. Cross participation among banks, and between banks and other financial institutions, seems to be limited. The banking market is concentrated, with the two largest banks accounting for about half of local banks' total assets, loans and deposits. Even so, there is no evidence of oligopolistic practices in the sector.

16. The steady growth of banking activity, mainly funded through retail deposits, has gone hand in hand with improvements in banks' financial performance. In 1998-2002, local banks'

\footnotetext{
${ }^{3}$ The policy of reserve accumulation was formalized in 1976, when the government passed a law requiring that 10 percent of all budget revenues be diverted to the reserve fund for future generations.

${ }^{4}$ Given the large government surpluses, budgetary issues appear to be a longer-term concern, rather than a source of near-term vulnerability.

${ }^{5}$ In 2001, member countries of the GCC decided to create a monetary union by 2010, and have already taken a number of key steps in that direction, including pegging their currencies to the U.S. dollar and adopting a uniform external tariff.
} 
total assets grew broadly at the same rate as nominal GDP, mainly driven by loans to customers. ${ }^{6}$ While banks' activity is still primarily funded by retail deposits, foreign funding has increased. As a result, the net foreign asset position of Kuwaiti banks has narrowed from 9.2 percent of GDP in 1998 to 3.8 percent in $2002 .^{7}$ Despite significant differences in banks' lines of business, average rates of return on both banks' assets and equities showed an upward trend, albeit one that was interrupted in 2002. Operating costs have remained broadly under control, although personnel expenses are quite significant in a few banks.

17. The Kuwaiti authorities have made some further progress in the past few years in bringing banking supervision into line with international standards. The CBK strictly enforces prudential safety and soundness requirements through both on-site and off-site supervision, and significant progress has been made in developing an early warning system. The central bank requires banks to institute comprehensive risk management programs that are commensurate with the size, nature, and scope of each bank's operations. The banks' risk management programs must address credit, liquidity, interest, market, and operational risks. Legislation was recently enacted that will bring Islamic financial institutions under the supervision of the CBK; and there are some challenges in extending supervision to such institutions (Box 2). The formulation of banking regulations and the implementation of supervision are broadly transparent.

18. An update of the 2000 assessment of the Basel Core Principles shows Kuwait as compliant or largely compliant with most of the principles and subprinciples. However, the CBK is not yet compliant with the principles related to consolidated supervision, information sharing, share transfers, international cooperation, and operations of foreign banks. The ability to share confidential supervisory information with appropriate governmental authorities and foreign bank supervisors would enhance domestic and international supervisory cooperation, as well as the consolidated supervision of the banks and their related parties. The foreign investment laws should be amended to provide for the entry of foreign banks, although the CBK will need to exercise vigilance in judging the effects on banking system soundness of changes in the competitive regime. The involvement of the MoFE in the CBK's decisions on licensing, closure, and administrative actions could ultimately compromise the CBK's independence in banking supervision. Legislative changes to eliminate the MoFE's involvement should be considered. Legislation currently before the national assembly, if enacted, would correct several of the issues identified in the assessment.

\footnotetext{
${ }^{6}$ Local banks' total assets slightly declined from 168 percent to 159 percent of nominal GDP over this period.

${ }^{7}$ Over the same period, the total short position of the Kuwaiti banking system has doubled from 0.4 to 0.8 percent of banks' capital.
} 


\section{Box 2. Regulation and Supervision of Islamic Financial Institutions}

Under Kuwaiti law, the CBK is responsible for the supervision, regulation, and licensing of deposit and nondeposit taking financial institutions operating in the Kuwaiti financial system. This authority includes investment houses, some of which operate according to Islamic financial principles. However, in the past, Islamic banks were not subject to registration and supervision by the CBK. Even so, the one existing Islamic bank has voluntarily subjected itself to CBK prudential regulations, guidelines, and standards, as well as reporting requirements. However, it was not legally within the supervisory jurisdiction of the CBK and is not subject to on-site inspections by the CBK.

Recently enacted legislation brings all Islamic banks under CBK supervision from December 2003, and provides for the licensing of new Islamic banks by the CBK. The existing Islamic bank has six months from the effective date of the legislation to file for an Islamic banking license with the CBK. Once a license is issued, the existing (or any other) Islamic bank becomes subject to CBK supervision. The CBK recently announced that it would initially limit to three the number of Islamic banks that it will license. This step was taken to promote a more competitive environment for Islamic banks and to allow the CBK to evaluate and refine its supervisory policies and instructions on Islamic banking.

The CBK has already developed examination programs and procedures for Islamic banks. However, there are some areas in which regulation and supervision could be strengthened further. These include the assessment of liquidity, regulatory standards for transparency and disclosure, and the Islamic legal underpinnings of financial transactions. Also, a further review of existing regulations will be needed to ensure that the specific risks in Islamic banking are adequately addressed. The CBK believes that its staff has an adequate understanding of the principles and practice of Islamic finance, acquired through outside training and experience in supervising Islamic investment houses.

\section{Non-Bank Financial Institutions}

\section{The number and weight of non-bank financial institutions have increased significantly} in the last few years. As of March 2003, there were 38 investment companies, 11 of which operate in accordance with the provisions of the Islamic law, and 37 investment funds (5 of which under Islamic law). Their total assets amounted to about 23 percent of the total assets of the financial system, without fully considering investment companies' off-balance sheet activity, which amounted to some KD 5.2 billion (about 41 percent of 2003 GDP), part of which is invested in domestic investment funds. ${ }^{8}$ While the activity of conventional investment companies is heavily concentrated in foreign markets, the core business of Islamic investment companies, which have been growing quickly in recent years, is domestic. In aggregate, both conventional and Islamic investment companies are well-capitalized at about 30 and 32 percent of their respective total assets. Investment companies are licensed and supervised by the CBK; 27 of the investment companies are also listed on the KSE and subject to KSE rules and regulations.

\footnotetext{
${ }^{8}$ Some third party assets managed by the investment companies might be invested in domestic investment funds.
} 
Table 2. Kuwait: Financial System Structure, 1998-2003

\begin{tabular}{|c|c|c|c|c|c|c|c|c|c|c|c|}
\hline & \multicolumn{3}{|c|}{1998} & \multicolumn{3}{|c|}{2000} & \multicolumn{3}{|c|}{2002} & \multicolumn{2}{|c|}{$20031 /$} \\
\hline & \multirow[t]{2}{*}{ Number } & \multicolumn{2}{|c|}{ Assets } & \multirow[t]{2}{*}{ Number } & \multicolumn{2}{|r|}{ Assets } & \multirow[t]{2}{*}{ Number } & \multicolumn{2}{|c|}{ Assets } & \multirow[t]{2}{*}{ Number } & \multirow{2}{*}{$\begin{array}{c}\text { Assets } \\
\text { (In Millions } \\
\text { KD) }\end{array}$} \\
\hline & & $\begin{array}{l}\text { (In Millions } \\
\text { KD) }\end{array}$ & $\begin{array}{c}\text { (In Percent of } \\
\text { Total) }\end{array}$ & & $\begin{array}{c}\text { (In Millions } \\
\text { KD) }\end{array}$ & $\begin{array}{c}\text { (In Percent of } \\
\text { Total) }\end{array}$ & & $\begin{array}{c}\text { (In Millions } \\
\text { KD) }\end{array}$ & $\begin{array}{c}\text { (In Percent of } \\
\text { Total) }\end{array}$ & & \\
\hline Banks & 10 & $12,875.1$ & 77.3 & 10 & $13,806.2$ & 78.2 & 10 & $17,063.8$ & 75.4 & 10 & $17,061.3$ \\
\hline Private & 9 & $12,511.1$ & 75.1 & 9 & $13,437.6$ & 76.1 & 9 & $16,623.4$ & 73.5 & 9 & $16,637.1$ \\
\hline Domestic & 8 & $12,326.6$ & 74.0 & 8 & $13,226.7$ & 74.9 & 8 & $16,350.7$ & 72.3 & 8 & $16,366.7$ \\
\hline Foreign & 1 & 184.5 & 1.1 & 1 & 210.9 & 1.2 & 1 & 272.7 & 1.2 & 1 & 270.4 \\
\hline State-owned & 1 & 364.0 & 2.2 & 1 & 368.5 & 2.1 & 1 & 440.4 & 1.9 & 1 & 424.3 \\
\hline Insurance companies & 17 & 270.5 & 1.6 & 17 & 307.9 & 1.7 & 17 & 354.0 & 1.6 & $\ldots$ & $\ldots$ \\
\hline Life and retirement & 6 & 33.4 & 0.2 & 6 & 38.6 & 0.2 & 7 & 49.4 & 0.2 & $\ldots$ & $\ldots$ \\
\hline Nonlife & 10 & 216.6 & 1.3 & 10 & 237.0 & 1.3 & 9 & 269.0 & 1.2 & $\ldots$ & $\ldots$ \\
\hline Reinsurance & 1 & 20.5 & 0.1 & 1 & 32.3 & 0.2 & 1 & 35.7 & 0.2 & $\ldots$ & $\ldots$ \\
\hline Other financial institutions & 43 & $3,503.9$ & 21.0 & 49 & $3,542.6$ & 20.1 & 71 & $5,199.8$ & 23.0 & 75 & $5,164.9$ \\
\hline Financial companies 2/ & 34 & $3,430.8$ & 20.6 & 37 & $3,411.4$ & 19.3 & 38 & $4,184.2$ & 18.5 & 38 & $4,156.8$ \\
\hline Investment funds & 9 & 73.2 & 0.4 & 12 & 131.1 & 0.7 & 33 & $1,015.6$ & 4.5 & 37 & $1,008.2$ \\
\hline Total financial system & 70 & $16,649.5$ & 100.0 & 76 & $17,656.6$ & 100.0 & 98 & $22,617.6$ & 100.0 & $\ldots$ & $\ldots$ \\
\hline Source: Kuwaiti authoriti & & & & & & & & & & & \\
\hline
\end{tabular}




\section{Securities Markets}

20. Kuwait has become the most active among the Arab stock exchanges in terms of turnover ratios. The first official stock exchange, an over-the-counter market, was opened in April 1977. Faced with the Suq al Manakh crisis in 1982, the government reorganized the exchange as the KSE or Suq-al-Awraq al-Maliyya under an Amiri Decree of 1983. Following the suspension of its operations with the Iraqi invasion, the exchange reopened in September 1992. A forward market was reintroduced in 1998. Trading on the KSE was opened to GCC citizens in May 1988, and subsequently to all foreigners in August 2000. Annual trade value amounted to KD 3,584.6 million, and KD 6,680.3 million as of the ends of 2001 and 2002, with turnover ratios of 50.3 percent and 75.0 percent.

21. The stock market has been on the rise at an accelerated pace in recent years. The KSE Index, after reaching its previous record high of 2,790 points in October 1997, dropped sharply throughout 1998, and continued to decline until it bottomed out at 1,318 points in January 2001. Since then, the index has been almost constantly on the uptrend, ending 2002 at 2,375 and reaching a new record high of 4,808 at end-December 2003-slightly more than doubling in 12 months.

22. The KSE is complemented by a clearing, settlement and depository company, stock brokers, and investment companies. Stock exchange trading is fully automated with the KATS, introduced in 1995. The KCC electronically carries out the settlements of all trades executed on the KSE and safe-keeps all securities traded on the KSE for investors. The 13 stockbrokers are licensed to carry out intermediate trades on the KSE. However, their functions are limited to order executions through terminals of the KATS and administrative operations for investors, and they are prohibited from providing investment advice. Any other capital market activities are either unregulated or outside the jurisdiction of the MC. These activities include investment advisory and fund management services by investment companies, which are supervised by the CBK.

\section{The regulatory environment for the securities market does not conform in significant respects to the IOSCO objectives and principles. In particular:}

- The development of the market is hampered by the lack of an appropriate legal and institutional framework. Owing to a multiplicity of laws and agencies, the principal agency, namely the $\mathrm{MC}$, is not able to effectively regulate and develop the market to ensure its efficiency, fairness, and transparency.

- $\quad$ The lack of an explicit prohibition of market manipulation and insider trading is a serious deficiency.

- The inspection, investigation, and surveillance powers of the regulating agency are materially inadequate and lack a clear process.

- $\quad$ Standards for market entry, prudential pre-requisites for licensing, and regulation of the issue market and market intermediaries are weak. Individuals are not licensed, and no proficiency requirements are in place for service providers. Owners, founders, operators, and managers are not subject to an adequate fit and proper assessment. 
- Internationally accepted accounting and auditing standards are not fully enforced across-the-board. While this is generally not the case for the rest of the economy, the CBK enforces such standards for the institutions it supervises. In addition, there is no legal provision requiring that auditors of financial service firms, who are complying with these standards, be selected on the basis of eligibility criteria to be developed by the regulating agency. ${ }^{9}$

\section{Numerous changes are thus needed to bring the securities regulatory and} supervisory system into closer conformity with international standards. The following measures are likely to be central:

- $\quad$ The creation by law of a single, independent, and accountable authority with full powers to regulate, supervise, and develop the securities market.

- $\quad$ Rules, regulations, and systems should be developed to deter and detect unlawful and fraudulent practices. Insider trading and market manipulation should be prohibited by law and enforced by establishing an inspection, investigation, and surveillance system.

- $\quad$ The law should clearly define entry standards for all types of market intermediaries and provide for prudential regulations governing their licensing, supervision, and performance. Owners and officers of licensed intermediaries should be subject to fit and proper conditions to be developed by the regulator.

- The regulator should build capacity to enforce disclosure requirements and to examine compliance of auditors and audited companies with internationally acceptable accounting and auditing standards.

- $\quad$ The regulator should arrange for continuing training programs for its staff.

The authorities are already making plans to implement a number of these changes. Further staff recommendations on improving the functioning of the securities markets is found in Section VI.B, below.

25. Some measures may also be desirable to mitigate the risks from excessive market swings. In the short run, it may at times be necessary to use moral suasion, possibly accompanied by a tightening of margin requirements and a further reinforcement of supervision of personal and trading credit (and indeed the CBK issued guidance in the second half of 2003 to this effect). Direct restrictions on (or intervention in) the market should not be necessary and are not advisable.

\footnotetext{
${ }^{9}$ Law No. 51/1994 amends some provisions of the Commercial Companies Law No. 15/1960, by requiring all companies listed on the KSE to have at least two external auditors.
} 


\section{E. Insurance}

26. The insurance sector in Kuwait is small, with total premium revenue of KD 94.6 million (about $\$ 315$ million) in 2002, or about 1 percent of GDP. This level of insurance penetration is generally in line with other Gulf states, but is significantly lower than the 3.4 percent of GDP for emerging markets and 9.0 percent for advanced economies. The market is served by seven Kuwaiti insurance companies - including two new insurers operating on Islamic principles - and ten foreign insurance branches from Arab and western countries. Non-life insurance products account for about 75 percent of the market; life insurance products (life and health insurance) account for the remainder. The four largest national companies collected about 75 percent of total premium income in 2002, benefiting from the requirement that only national companies may bid for insurance contracts from government-owned companies. In 2002, the national insurance companies ceded 63 percent of their non-life premiums to international reinsurance companies ( 94 percent for property insurance). In this respect, the national insurance companies function more as insurance brokers than underwriters. The four largest national companies are highly capitalized and profitable, and earn most of their income from investments and reinsurance commissions, rather than from underwriting for their own account.

27. Supervision of the insurance sector rests with the insurance department in the MoCI. An informal review of the observance of the IAIS core principles for insurance supervision showed that the scope of regulation and supervision is defined by a 40 -year old law that lacks many key elements of a modern insurance supervision regime. The law includes adequate provisions for financial reporting and on-site inspections, as well as a (high) minimum capital requirement and deposit reserve requirements. However, the focus of the law is on regulation and compliance, and the supervisor does not have the mandate, powers, or capacity to undertake a thorough analysis of possible financial and operational risks. There is thus a need to strengthen supervision and enhance its independence, for example by creating an independent agency. Even short of this, DI's capacity could be enhanced by hiring a senior advisor with expertise in insurance supervision, obtaining expert advice on developing supervisory guidelines for underwriting, liability management and reinsurance, and adding staff with industry experience.

\section{F. Anti-Money Laundering/Combating the Financing of Terrorism}

28. Although Kuwait's AML system has been reinforced, some significant deficiencies remain in the legal and regulatory framework. A major development in strengthening the AML systems was the enactment of Law 35/2002, combined with the implementation of subsidiary rules by some of the regulators. However, this legislation has yet to be extended formally to cover the broad financial sector; and there are currently distinct variations in the level of compliance testing applied to the different sectors (with notable weaknesses in the gold and equities markets). The financing of terrorism has not been criminalized, although the authorities have taken robust measures to prevent the abuse of charitable organizations.

29. Despite the progress made in recent years to strengthen the overall AML system, there are areas in which further work is required as a matter of some urgency. There is a need to restructure the FIU to give it greater independence of operation, including the capacity to cooperate with foreign counterparts; to lower the level of suspicion required for the filing of 
suspicious transactions reports; to implement adequate "fit and proper" tests for the ownership and management of non-bank financial institutions; to criminalize insider dealing and market manipulation; and to create effective gateways and procedures for international co-operation with respect to both mutual legal assistance and regulator-to-regulator exchange of information. In addition, it is essential that explicit provisions relating to the financing of terrorism be incorporated in national law.

\section{SySTEMIC LiQuidity AND CRISIS MANAgEMENT}

\section{A. Monetary Instruments and Operations}

30. Monetary policy in Kuwait is determined and implemented by the CBK in accordance with the Central Bank Law. The CBK has considerable operational independence, although by law the CBK board's decisions on monetary and credit policies can be suspended and sent for referral to the MoFE, which can issue binding instructions to the CBK board. ${ }^{10}$ The CBK has been operationally effective in achieving its principal monetary policy objective, which is to ensure the stability of the exchange rate under an open and liberalized exchange and trade system. ${ }^{11}$ In early 2003 , the exchange rate peg was redefined in terms of the U.S. dollar in line with the decision of the GCC. ${ }^{12}$ In these circumstances, domestic interest rates have been closely aligned with interest rates abroad, while monetary aggregates have been demand-determined. As a short-term objective, the CBK also aims to stabilize interest rates, particularly the 30 -day interbank rate.

\section{The CBK relies on both market-based and administrative instruments of} monetary policy. The CBK's most actively used instrument to manage domestic liquidity is its deposit facility. The CBK conducts a weekly deposit auction for banks; and in addition throughout the week it permits banks to deposit as much as they wish at rates set by the CBK, generally slightly below the interbank rate. The CBK uses these instruments both to absorb liquidity and, within limits, to add liquidity. The CBK does not impose any reserve requirements, but uses a liquidity requirement and a maturity ladder to regulate banks' liquidity. ${ }^{13}$ In addition, a temporary liquidity requirement that depends on the risk characteristics of each bank has been imposed in connection with the removal of the implicit

${ }^{10}$ If such instructions are challenged by the CBK board, the matter is decided by the Council of Ministers.

${ }^{11}$ Kuwait maintains no exchange restrictions subject to Fund jurisdiction, and has liberalized many international capital movements, notably credit transactions. However, Kuwait still maintains controls on inward direct investment, certain securities transactions, and real estate.

12 Previously, Kuwait pegged the dinar to a basket of currencies.

${ }^{13}$ The liquid asset ratio requires banks to hold government securities equal to at least 20 percent of their private Kuwaiti dinar deposits, primarily for prudential purposes. The maturity ladder primarily serves a prudential purpose. 
government guarantee on deposits. The CBK maintains an unsecured overnight lending facility at a penalty rate, which has for some time been unchanged at 10 percent. ${ }^{14}$ The CBK also maintains ceilings on bank lending rates that are tied to the discount rate. ${ }^{15}$ The CBK is presently working on bringing the Islamic banks into the monetary framework (the major Islamic bank does not participate in the CBK's deposit facility, nor does it hold government securities).

32. Although the existing monetary framework is satisfactory in most respects, the use of marketable instruments in monetary operations could help to foster financial market development. Securities that could be used in monetary operations in lieu of nonmarketable deposits include government bills or bonds, CBK bills (which would need to be reintroduced), or mortgage-backed securities (if and when such a market develops). It is relevant to note in this connection that at present the CBK has no government securities in its portfolio with which to conduct open market operations, in part because most government securities are needed by the banks to meet the liquidity requirement. Indeed, the aggregate amount of treasury bills and bonds outstanding may be becoming insufficient for banks to meet the liquidity requirements. The development of open market operations using government securities would thus require some supporting measures to ensure that adequate supplies are available for monetary operations. ${ }^{16}$

33. It would also be desirable to ease or remove the lending rate ceilings. This step could facilitate increased lending to SMEs, lead to better pricing of risks, and thus support efficient private sector growth. The CBK has been moving in this direction by abolishing the rigid interest rate structure that imposed ceilings and floors on various categories of deposits and lending. At present, the ceiling on lending rates remains as a legal requirement (Article 111 of the Commercial Law); therefore removing this ceiling will require an amendment to the

${ }^{14}$ In general, all central bank lending to banks should be collateralized. However, CBK officials point out that most banks maintain sufficient government securities with the CBK to cover their borrowing from the central bank.

${ }^{15}$ Rates on loans with maturities up to one year cannot exceed 5.75 percent per year ( 250 basis points over the discount rate, which currently stands and 3.25 percent), while loans over one year are limited to 7.25 percent (400 basis points over the discount rate). There are also a number of other quantitative limits on consumer lending on the individual consumer and at the bank level. These limits on consumer and personal loans are imposed both for prudential and resource allocation reasons.

16 These may include lifting the ceiling of KD 3 billion on the stock of government bills and bonds. Another possible step would be to ease the liquidity requirement, by lowering the ratio, allowing banks to include their balances with the CBK in meeting it, or permitting banks to meet this requirement on average over a stated period (rather than every day). However, owing to current excess liquidity and prudential considerations, especially those associated with the removal of the implicit deposit guarantee, it may be inadvisable to ease the liquidity requirements in the short term. Even so, they should be simplified as soon as prudential considerations permit. 
Commercial Law. The CBK might also consider reducing the penalty on the marginal lending facility, and tie it more closely to a market rate, which could reduce volatility in the interbank overnight rate.

34. Monetary policy transparency is relatively high, although there are some areas for improvement. The roles, responsibilities, and objectives of the $\mathrm{CBK}$ in the area of monetary policy are clearly spelled out in the CBK Law, and are disseminated on the CBK's website, in its annual reports, and in other forms. The CBK has an active publication program. The process for reporting monetary decisions and their explanation is well-developed, but could be more comprehensive. In particular, meetings of the Board of Directors when it considers monetary policy issues could be announced in advance, and reported on in a more systematic way. Even so, the governor and other high officials devote considerable time to keeping the public informed on monetary policy, including through speeches that are available on the CBK's website. The accountability and assurances of integrity by the CBK are also good, including regular financial reporting and appearance of officials before the national assembly. There could be more public disclosure relating to the conduct of personal financial affairs of CBK staff and legal protections for CBK staff in the conduct of their official duties.

\section{B. Money Market}

35. Kuwait has a fairly active interbank money market, although several factors constrain the market at present, including high levels of bank liquidity. A few major corporate customers also participate in the market, but foreign banks are not allowed to borrow in it, although they may lend. Total volume in the interbank market averaged approximately KD 3.7 billion and 3.9 billion per month in 2001 and 2002, respectively. The bulk of activity is in interbank deposits of one month, although some of the deposits are for three months, one week, and overnight. Most of this lending is unsecured, and participants therefore set individual limits on their counterparties. In addition to the interbank market, the CBK frequently auctions treasury bills of three and six months' maturity in the primary market.

\section{Payment System}

36. The Kuwaiti payment system is still strongly oriented to the use of banknotes for retail-level transactions, and checks continue to play a role in the settlement procedures of the equity clearing system and loan sharking. ${ }^{17}$ However, in response to CBK encouragement, the banking community has made a significant start toward electronic transactions. For bank-to-bank transactions, the SC system operated by the CBK for 11 institutions plays a central role. It handles about 200 million KD per day among the banks, and is thus of systemic significance. It does not fully observe 2 or 3 of the 10 Core Principles for such systems, primarily those relating to the completeness of the system rules and procedures and to governance arrangements. On the other hand, the SC system appears to satisfy the immediate needs of its users.

${ }^{17}$ The observations in this section are based in part on an informal review of observance of the Core Principles for Systemically Important Payment Systems. 
37. Oversight and development of the payment system rests with the CBK, as specified in the CBK Law. The CBK has discouraged the use of paper checks, and has successfully encouraged the creation of a national banking community network for shared ATMs and POS terminals. It has managed the construction of the RTGS system to permit large value transfers to clear and settle with immediate finality. ${ }^{18}$ However these steps have not been accompanied by clearly stated policy objectives and plans for the payment system. Nevertheless, the CBK has disclosed its decision to introduce an RTGS system to a wide range of bodies, public and private. In addition, the CBK should set out, at least in a short statement, its plans and policies for the payment system, including the promulgation of regulations on the finality characteristics of the RTGS transfers and, if necessary, the procedures to be followed in case intra-day liquidity injections are required.

38. In addition, consideration should be given to the following improvements in payment systems policies. The requirement of Core Principle 3 that the existing SC should have clearly defined procedures for the management of credit risk has not been fulfilled, possibly giving rise to moral hazard. As stated elsewhere in this paper, the CBK's supervision of the banks includes requirements for policies relating to credit risk. Core Principle 3 could be met by the regulations for the SC (and the RTGS system, when live) including a reference to these requirements. The requirement of Core Principle 9 that the SC should have objective and publicly disclosed criteria for participation has also not been fulfilled. The desires of newly created Islamic institutions and additional branches of banks from other GCC countries for participation in the SC will render this lack of transparency more of a problem than it has been to date. This has been recognized by the CBK, and criteria will be developed for participation in the RTGS system.

\section{Lender of Last Resort and Deposit Insurance}

39. In recent years, the CBK has not needed to provide emergency lending to the banking sector. Contingency procedures exist should they be required. The CBK has authority to engage in emergency lending under Article 41 of the Central Bank Law, which gives the CBK power to provide loans and advances in emergency cases for a period of up to six months, with collateral considered to be adequate by the CBK. In the past the CBK has provided broad emergency support to banks in the context of the Suq al Manakh financial crisis in 1982, and the Iraqi invasion of 1990.

40. The government now implicitly guarantees all bank deposits in Kuwait, although the authorities intend to remove this implicit guarantee in the near future. In 1992, to restore confidence in the banking system after the Iraqi invasion, the government publicly committed to guarantee all bank deposits, although the guarantee was not formalized in law. Market participants continue to operate under the assumption that the full guarantee remains in place. As a practical matter, banks that have experienced problems in the past have received assistance, thus precluding the need to compensate depositors. The authorities realize that the

${ }^{18}$ The preparations for a RTGS system are well advanced, but implementation has been delayed by the uncertainties associated with the military activity in Iraq in early 2003. The commencement of RTGS operations now has a target date of April 2004. 
current system increases moral hazard, reduces market discipline, and could prove costly to the government. They intend to remove the guarantee in the near future and communicate this decision to the public.

41. In preparation for the removal of the guarantee, the banking supervision department has reinforced liquidity requirements on banks. While some differentials in deposit rates, and associated flows of deposits, may emerge as the market differentiates among institutions, the authorities believe that these will not be seriously disruptive. As a precaution, however, special liquidity requirements have been put in place. These became effective in October 2003 and require banks to maintain a liquidity ratio that varies from 25 percent to 35 percent, depending on the bank's CAMEL rating and other measures of financial strength.

42. The authorities do not plan to implement deposit insurance when the guarantee is removed. Their rationale is that the bulk of deposits are held by large depositors who, owing to cost considerations would probably not be covered by any deposit insurance scheme. Moreover, these large depositors are aware of the systemic repercussions of their actions. By contrast, small depositors do not account for a very significant proportion of total deposits, are not a threat to systemic stability, and might be compensated in ways other than by deposit insurance.

43. The staff recommends the development of a funded deposit insurance scheme for small depositors. Such a scheme would not be particularly costly, and may also be desirable on social policy grounds. More importantly, in the absence of any deposit insurance, the likelihood of a run by small depositors may be increased. If the provision of lender-of-lastresort support to potentially insolvent institutions is to be avoided in accordance with good practices, the authorities may in any event need to be prepared to step in with renewed support for depositors if a run is to be stopped.

\section{E. Resolution of Troubled Institutions}

44. The CBK believes that it has adequate powers for dealing with problem banks, should they develop. At present, the emergence of banking problems is unlikely as all the banks are well-capitalized, and are closely supervised by the CBK (for example, the CBK recently took steps to replace the management of a bank with questionable accounting practices). The CBK could take any or all of the following actions to prevent the failure of a bank: (i) prohibit the bank from engaging in certain activities; (ii) set limits on the bank's business; (iii) appoint a temporary controller to supervise the bank; and (iv) take over management of the bank for a period of time and determine the viability of the bank. If these measures proved insufficient, a decision to close a bank, or to merge it with another bank, would have to be issued by the MoFE based on a recommendation of the Board of Directors of the CBK (Article 63 of the Central Bank Law). ${ }^{19}$

${ }^{19}$ Article 65 of that law specifies that if such a decision is rendered to delete a bank from the Register of Banks, after first giving it an opportunity to express its views, the bank must be liquidated. 
45. The proposed amendment to the CBK Law will strengthen these powers considerably. If enacted, the CBK will be empowered to remove or change staff, deem a director as unqualified, or dissolve a board of directors and appoint a commissioner to run the bank pending the appointment of a new board. However, revocation of the banking license would still require approval by the MoFE, as would the approval or arrangement of a bank merger. The staff recommends that these two powers be left to the sole decision-making authority of the CBK board so as to enhance its independence and effectiveness in dealing with troubled banks.

46. To date, no bank in Kuwait has been closed or had its license revoked. During the Suq Al Manakh crisis and the Iraqi invasion and occupation, the CBK and the government supported the entire banking system. These interventions were in response to systemic risks posed by these crises to the entire banking sector and economy as a whole. However, CBK officials indicated that they would not bail out a troubled bank in the future, and would instead take control of the bank and write the shareholders' net worth down to zero. The staff encouraged the authorities to inform the banks and the public of this policy.

\section{VULNERABILITIES AND SOUNDNESS OF THE FINANCIAL SYSTEM}

\section{A. Risks to Financial Stability}

47. The Kuwaiti economy is highly dependent on oil and vulnerable to oil price fluctuations. The oil sector represents almost half of total domestic production and generates 91 percent of export earnings and more than two thirds of government revenue, leaving the fiscal and external balances subject to significant fluctuations. However, the direct exposure of Kuwaiti banks to the oil sector is modest, and the government seeks to protect the economy from fluctuations in oil prices through its stabilization fund.

48. There may be some risks from the recent run-up in the stock market, which reflects high liquidity in the system, declining interest rates and limited investment opportunities available to the private sector. The index reached new highs in 2002, and doubled again in 2003. A sharp decline in equity prices could result in the insolvency of some investors, lower the net worth of firms and households, and reduce economic activity. A steep declines in stock prices could lead to an increase in NPLs and a tightening of bank credit.

49. A related source of potential vulnerability is banks' exposure to real estate. Real estate activity rose to its highest level in years, with sales of property increasing by 56 percent in 2002. According to the CBK, real estate lending by commercial banks increased by 25 percent in 2003 (12 months change to June). A decline in real estate prices, triggered by an interest rate hike or a drop in stock market prices, would lead to a decline in the value of collateral and an increase in NPLs.

\section{B. Banking Sector}

50. By and large, Kuwaiti banks are well capitalized, highly liquid, and the quality of their assets has improved over time, albeit unevenly (Table 3). Despite a downward trend, the average CAR remains well above the statutory minimum of 12 percent. Since 1999, 
Table 3. Kuwait: Financial Soundness Indicators for the Banking Sector, 1999-2003

(In percent, unless otherwise indicated; end of period)

\begin{tabular}{|c|c|c|c|c|c|}
\hline & 1999 & 2000 & 2001 & 2002 & $\begin{array}{c}\text { March } \\
2003\end{array}$ \\
\hline \multicolumn{6}{|l|}{ Capital adequacy } \\
\hline Regulatory capital to risk-weighted assets $(*)$ & 23.7 & 22.2 & 22.0 & 19.7 & 19.0 \\
\hline Regulatory Tier I capital to risk-weighted assets $\left({ }^{*}\right)$ & 22.9 & 21.8 & 20.7 & 18.3 & 17.6 \\
\hline Capital (net worth) to assets & 12.6 & 12.4 & 12.2 & 11.1 & 11.3 \\
\hline \multicolumn{6}{|l|}{ Asset composition and quality } \\
\hline \multicolumn{6}{|l|}{ Sectoral distribution of loans to total loans $(*) 1 / 2 /$} \\
\hline Real estate & 19.9 & 16.3 & 19.0 & 18.6 & 18.3 \\
\hline Personal facilities & 31.9 & 32.1 & 33.0 & 37.4 & 37.8 \\
\hline Of which: Credit for trading & 4.3 & 4.7 & 6.3 & 5.7 & 5.9 \\
\hline Credit for residential & 9.3 & 9.8 & 9.0 & 7.4 & 9.9 \\
\hline Trade & 18.5 & 18.4 & 17.5 & 14.7 & 13.4 \\
\hline Industry & 6.2 & 6.1 & 6.4 & 6.7 & 6.9 \\
\hline Construction & 6.1 & 8.4 & 6.1 & 6.9 & 6.8 \\
\hline Financial institutions & 7.2 & 6.3 & 11.6 & 9.2 & 9.0 \\
\hline Other & 10.2 & 12.4 & 6.4 & 6.5 & 7.8 \\
\hline FX loans to total loans $2 /$ & 23.5 & 21.4 & 19.1 & 20.4 & 19.2 \\
\hline Impaired loans to gross loans $(*) 3 /$ & 9.9 & 9.9 & 8.0 & 5.6 & 5.4 \\
\hline Provision to gross loans & 6.8 & 6.4 & 5.5 & 5.0 & 4.8 \\
\hline Total provision to impaired loans 3 / & 71.1 & 66.8 & 70.7 & 91.2 & 91.0 \\
\hline of which: specific provision & 54.4 & 49.7 & 49.4 & 60.3 & 59.1 \\
\hline Impaired loans net of provisions to capital $(*) 3 /$ & 29.1 & 32.1 & 25.6 & 16.1 & 16.4 \\
\hline Large exposures to capital $(*) 4 /$ & 113.9 & 115.7 & 105.6 & 134.9 & 113.9 \\
\hline \multicolumn{6}{|l|}{ Earnings and profitability } \\
\hline $\operatorname{ROA}(*) 2 /$ & 1.8 & 2.0 & 2.0 & 1.8 & 2.0 \\
\hline $\operatorname{ROE}(*) 2 /$ & 15.3 & 17.6 & 18.2 & 17.4 & 18.2 \\
\hline Interest margin to gross income $(*)$ & 30.4 & 33.0 & 37.0 & 41.0 & 44.3 \\
\hline Noninterest expenses to gross income $(*)$ & 17.6 & 16.3 & 19.9 & 22.3 & 24.7 \\
\hline Personnel expenses to noninterest expenses & 46.8 & 48.1 & 44.1 & 48.7 & 44.9 \\
\hline Trading and fee income to total income & 10.5 & 10.3 & 12.7 & 17.2 & 18.3 \\
\hline Spread between reference loan and deposit rates 5/ & 283.0 & 296.0 & 336.0 & 333.0 & 301.0 \\
\hline Stock price index of bank shares & 104.7 & 124.9 & 147.0 & 137.7 & 119.2 \\
\hline \multicolumn{6}{|l|}{ Liquidity } \\
\hline Liquid assets to total assets $(*) 2 / 6 /$ & 17.8 & 21.2 & 24.3 & 21.2 & 18.3 \\
\hline Liquid assets to total short-term liabilities $\left(^{*}\right) 7 /$ & 25.6 & 31.1 & 34.9 & 32.1 & 27.0 \\
\hline Customer deposits to total (non-interbank) loans $2 /$ & 134.1 & 139.3 & 147.4 & 130.3 & 123.6 \\
\hline FX liabilities to total liabilities & 20.4 & 19.8 & 19.2 & 22.4 & 21.5 \\
\hline \multicolumn{6}{|l|}{ Sensitivity to market risk } \\
\hline Net open position in FX to capital (*) 8/ & 0.4 & 0.3 & 0.9 & 0.8 & 0.2 \\
\hline Net open position in equities to capital & $\ldots$ & $\ldots$ & $\ldots$ & $\ldots$ & $\ldots$ \\
\hline \multicolumn{6}{|l|}{ Source: CBK } \\
\hline $\begin{array}{l}\text { (*) Included in the "core set" of FSIs. } \\
\text { 1/ Total loans represent credit facilities to reside } \\
\text { 2/ Includes Kuwait Finance House. } \\
\text { 3/ Includes "special mention" loans and exclude } \\
\text { 4/ Aggregate of exposures that are higher than } 1 \\
\text { 5/ In basis points. } \\
\text { 6/ The definition of liquid assets includes cash, } \\
\text { 7/ Short-term liabilities are those liabilities with } \\
\text { 8/ Short position. }\end{array}$ & $\begin{array}{l}\text { itutions. } \\
\text { Ides impai } \\
\text {, divided } \mathrm{x} \\
\text { treasury b }\end{array}$ & $\begin{array}{l}\text { ed credi } \\
\text { y banks' } \\
\text { lls and b }\end{array}$ & $\begin{array}{l}\text { ities bef } \\
\text { capital }\end{array}$ & raqi inva & \\
\hline
\end{tabular}


impaired loans for the banking system as a whole almost halved, declining to 5.4 percent of gross loans by the first quarter of this year. ${ }^{20}$ Specific provisions increased somewhat and reached, on average, 60 percent of total impaired loans. ${ }^{21}$ This ratio varies significantly among banks - as of March this year, it ranged between 16 percent and 75 percent - partially reflecting the differing importance of collateralized loans in banks' portfolios. ${ }^{22}$ Despite a recent decline, Kuwaiti banks' liquidity position is, on average, strong. ${ }^{23}$

51. Market and liquidity risks are limited. Owing to the very short-term maturity of financial instruments in the market, tight controls on banks' foreign exchange exposure, and the limited range of movements in interest rates and exchange rates under the highly credible pegged exchange rate regime, vulnerability to interest rate and exchange rate risks is limited. ${ }^{24}$ However, banks could be vulnerable to indirect exchange rate risk, since a good part of bank loans in foreign currency - amounting to almost 20 percent of total loans - is directed to nontradable good sectors. Given the central bank liquidity requirements and the overall stability of deposits, liquidity risk seems to be limited as well, although in a few cases liquid assets fall short of the total amount of deposits of the ten largest financial sources, and in the case of at least one bank, the maturity mismatch might be a source of concern.

\section{Banks are more sensitive to credit risk, although the likelihood of a shock sufficiently large to pose systemic problems appears to be fairly small. For example, sufficiently adverse macroeconomic developments, such as a significant drop in oil prices combined with a sharp correction in real estate and equity prices, might have an adverse impact on the financial soundness of Kuwaiti banks.}

53. Two separate methods were used in bank stress testing. The first analyzed the sensitivity of banks' CAR to changes in the amount and distribution of impaired loans, also

\footnotetext{
${ }^{20}$ The official definition of NPLs includes "special mention" loans. This report will continue to apply the official definition of NPLs but it will use the more general term "impaired loans," and the amount of interest in suspension will be excluded.

${ }^{21}$ If general provisions are considered, the coverage ratio jumps to 91 percent.

${ }^{22}$ The value of collateral is subtracted from the required provisions to determine the level of actual provisions to be established. The large difference between required and actual provisions can be explained by banks' tight requirements on collateral. Nonetheless, some questions arise on the proper valuation (and economic meaning) of collateral. According to CBK instructions, the value of collateral is to be calculated on the basis of "recent market value" after adjusting this value downward by ratios that cover systemic, exchange and other risks, according to the quality of the specific collateral and in coordination with the external auditors. However, if the value of the collateral is quite strong the question remains why the banks do not liquidate them and rid themselves of the problem loans.

${ }^{23}$ Liquid assets include treasury bills and bonds.

${ }^{24}$ A measure of banks' overall maturity gap and open position in foreign currency was used to measure banks' vulnerability to interest and exchange rate risk.
} 
taking into account potential losses in the value of outstanding collateral that would force banks to make additional provisions. ${ }^{25}$ The second (reported in Table 4) sought to investigate the resilience of the banking system to shocks. Two scenarios were envisaged. In the first scenario (mild shock), it is assumed that the spread between domestic and foreign (U.S.) interest rates widens modestly (13 basis points) ${ }^{26}$ while the U.S. dollar depreciates a further 10 percent with respect to main currencies; ${ }^{27}$ some slowdown in the economy is reflected in a one notch downgrade of all loans (in domestic and foreign currency); no sectoral shock is considered. In the second scenario (severe shock), the interest rate spread widens by 50 basis points; all loans are downgraded by two-notches; and in addition, 25 percent of personal facilities to trade in shares and 10 percent of real estate loans turns into bad debt; and a 50 percent haircut on collateral value is imposed.

54. The results broadly confirm the resilience of the banking system, although a few remarks are called for. As noted above, shocks have to be quite substantial to threaten the financial soundness of the banking system. However, a few banks show a particular vulnerability to changes in the value of collateral. In particular, large shocks in the real estate sector and the stock market could have significant consequences for these banks; and the bank that shows the highest sensitivity to deterioration in the quality of loans in these two sectors plays a crucial role in the Kuwaiti banking system. Strong supervisory enforcement, complemented if necessary by moral suasion, may be needed as an antidote to these potential vulnerabilities. The authorities have already taken steps in this direction.

55. Over the medium term, the continued stability of banking system will depend to some extent on the pace of structural reform in Kuwait. The development of a strong and diversified private sector would be instrumental to boost banks' investment opportunities. The removal of caps on interest rates as well as the lifting of the blanket deposit guarantee will foster efficiency and market discipline.

\section{Non-Bank Financial Institutions}

56. While the vulnerability of the insurance sector seems limited, closer attention to the activities of investment companies might be called for in light of their growing importance in the Kuwaiti financial system. In the last two years, investment companies have increasingly relied upon bank credit as a source of financing (from 7.5 percent of their

\footnotetext{
${ }^{25}$ As a working hypothesis, it is assumed that banks are required to make additional provisions that amount to 50 percent or 100 percent of the difference between current level of specific provisions, which factors in collateral, and the level of specific provisions that would prevail without collateral.

${ }^{26}$ Domestic interest rates are shocked by one standard deviation that is computed using rolling data windows of 12-month length.

${ }^{27}$ In light of the strong reserve position of the CBK and the large stock of foreign assets of government-related agencies, the exchange rate between the $\mathrm{KD}$ and the $\mathrm{U}$. S. dollar is assumed to remain unchanged.
} 
Table 4. Kuwait: Local Banks’ Stress Test Results

\begin{tabular}{|c|c|c|c|c|c|c|c|c|c|c|}
\hline & \multicolumn{3}{|c|}{ Pre-Shock } & \multicolumn{3}{|c|}{ Profits and Losses Due to: $1 /$} & \multicolumn{3}{|c|}{ Post-Shock } & \multirow{2}{*}{$\begin{array}{l}\text { Number } \\
\text { of Banks } \\
\text { CAR }<12\end{array}$} \\
\hline & $\begin{array}{c}\text { Impaired } \\
\text { loans 2/ }\end{array}$ & Prov. 3/ & CAR & Interest & Ex. Rate & Prov. & $\begin{array}{c}\text { Impaired } \\
\text { loans } 2 / \\
\end{array}$ & Prov. 3/ & CAR & \\
\hline \multicolumn{11}{|l|}{ Mild shock 4/ } \\
\hline No change in collateral & 5.5 & 59.1 & 18.3 & 0.0 & 0.3 & -2.5 & 6.5 & 57.6 & 18.0 & 0 \\
\hline 50 percent haircut on collateral & 5.5 & 59.1 & 18.3 & 0.0 & 0.3 & -6.4 & 6.5 & 66.2 & 17.2 & 0 \\
\hline 70 percent haircut on collateral & 5.5 & 59.1 & 18.3 & 0.0 & 0.3 & -7.2 & 6.5 & 67.9 & 17.1 & 1 \\
\hline \multicolumn{11}{|l|}{ Severe shock 5/ } \\
\hline \multicolumn{11}{|l|}{ No sectoral shock } \\
\hline No change in collateral & 5.5 & 59.1 & 18.3 & 0.1 & 0.3 & -5.9 & 7.4 & 57.9 & 17.4 & 0 \\
\hline 50 percent haircut on collateral & 5.5 & 59.1 & 18.3 & 0.1 & 0.3 & -5.7 & 7.4 & 65.4 & 16.7 & 1 \\
\hline \multicolumn{11}{|l|}{ Sectoral shock } \\
\hline No change in collateral & 5.5 & 59.1 & 18.3 & 0.1 & 0.3 & -21.5 & 10.1 & 69.5 & 14.5 & 3 \\
\hline 50 percent haircut on collateral & 5.5 & 59.1 & 18.3 & 0.1 & 0.3 & -25.3 & 10.1 & 75.0 & 13.8 & 5 \\
\hline
\end{tabular}

\section{Sources: CBK; and IMF staff estimates.}

1/ In percent of preshock capital.

2/ Impaired loans net of interest in suspense; includes "substandard" loans; in percent of gross loans, net of interest in suspense.

3/ Specific provisions in percent of impaired loans.

4/ One standard deviation (13 basis point) increase in domestic interest rate; 10 percent depreciation of the U.S. dollar vis-à-vis major currencies that implies a 7.7 depreciation of the nominal effective exchange rate of the Kuwaiti dinar; 1 notch downgrade of loans. Collateral haircut implies an increase in provision equal to 50 percent of the difference between required (without collateral) and current level of provisions.

5/ Fifty basis point increase in domestic interest rate; 10 percent depreciation of the U.S. dollar vis-à-vis major currencies that implies a 7.7 depreciation of the nominal effective exchange rate of the Kuwaiti dinar; 2 notches downgrade of loans. Sectoral shocks: 25 percent of personal facilities to trade in shares, which is increased ad hoc by 25 percent, and 10 percent of credit to real and construction sectors turn into bad debt (100 percent provision). 
total liabilities in 2000 to about 13 percent in 2002). Concerns about their liquidity position might arise if the maturity mismatch between their assets and liabilities continued to worsen. Some of the investment companies may be relying on credit lines from foreign banks; however, in difficult times these credit lines may be withdrawn and thus turn out to be elusive when most needed. The potential for systemic risk arising from the financial linkages between local banks and investment in the stock market appears to be contained at present, reflecting CBK regulations limiting investment companies' leverage and the relatively small exposure of local banks to investment companies. ${ }^{28}$ However, the compilation of more detailed and comprehensive data on these linkages is advisable in light of the potential risks.

\section{Key Structural Issues AfFecting Financial StabiLity}

\section{A. Legal System}

\section{The laws and institutions underpinning Kuwait's financial and commercial} sectors are mostly satisfactory but some need updating. Many legal norms were designed a generation ago and for a business culture based mainly on personal and family relationships. There has been little movement toward adopting laws that create an enabling environmentfor private sector growth in a regional or global economy. ${ }^{29}$ The judiciary in Kuwait is generally well regarded. Court procedures are broadly efficient, respect for and compliance with the law is high, judges are well paid and independent, cases of corruption are rare, and the court infrastructure is good.

58. Laws and procedures for insolvency and debt recovery appear to be broadly adequate. Some attention might be given to revising the bankruptcy provisions to create a more efficient exit mechanism for failed companies (presently, the use of the legislation to promote reorganizations or workouts is almost nonexistent). Procedures for the recovery of debts and enforcement of security appear satisfactory, although they can sometimes be drawn out. The real estate and commercial registers appear to be efficient. For housing loans that are unsecured, attachment of salaries is usually effective in securing repayment. The ability of the courts to impose a travel ban also has a salutary effect on the repayment of debt.

59. There is also scope to strengthen corporate governance. Entities subject to CBK supervision, and listed companies, have adequate governance arrangements. Even so, a revision of the Law on Commercial Companies (No. 15 of 1960) could help to improve matters in the rest of the commercial sector, where there is little awareness and understanding

${ }^{28}$ At the end of 2002, local banks' lending to investment companies amounted to approximately 9 percent of local banks' total lending portfolios and 32 percent of bank stockholders' equity.

${ }^{29}$ Examples include: (i) formation of a shareholding company requires the issuance of an Amiri Decree and can take months; and (ii) a representative of the $\mathrm{MoCI}$ is required to be present at all shareholder meetings. 
of current standards of disclosure, governance, the liability of the Board of Directors, and the role of auditors.

\section{B. Securities Markets}

60. Changes in the stock market's operations may help to improve its functioning and mitigate excessive one-way movements and the associated risks:

- $\quad$ Short selling might be introduced as the regulatory and legal framework is strengthened, accompanied by adjustments in the regulation of margin trading. A more balanced use of short selling and margin trading by dealers or speculators would help to smooth out market movements, while maintaining market liquidity.

- Given the liquidity of the market, the affluence of investors, and the robustness of the trading and settlement systems, a case can also be made for diversifying product lines and liberalizing foreign participation.

- $\quad$ Though investment companies provide advisory services, stockbrokers are prohibited from offering such services. As a result, information intermediation, which is a core function of a capital market, is largely absent. The role of market intermediaries should be redefined in conjunction with the more general overhaul of the securities regulatory framework.

To some extent, changes in this direction are already envisaged in the comprehensive fouryear work plan developed by the stock exchange ("Kuwait Stock Exchange Development Strategy").

61. The stability and efficiency of the financial system could also be enhanced by developing corporate and government bond markets to complement equity and bank finance:

- $\quad$ The development of a corporate bond market would be desirable to provide a longterm funding source to the real economy and alleviate stresses on the banking system by allowing banks to obtain some of their funding longer-term. The corporate bond market in Kuwait is small compared to the country's bank loan and equity markets, although it has been growing as a funding source for banks' consumer loans. ${ }^{30} \mathrm{~A}$ CBK regulation of 2000 prompted banks to issue corporate bonds, by allowing banks to make consumer loans up to 30 percent of the proceeds from a bond issue (by contrast, consumer lending funded by deposits is capped at 12 percent of deposits). Corporate bonds in the Kuwaiti market are seldom traded, though they are listed on the KSE. They are either in bearer form or in book-entry form, and settle at KCC. Most corporate bond investors are institutions and high net worth individuals.

${ }^{30}$ The outstanding balance of KD and U.S. dollar corporate bonds in the Kuwaiti market stood at KD 369 million and \$775 million, respectively, at the end of August 2003. 
- $\quad$ A more developed government bond market could also stimulate the provision of long-term finance and enhance the contribution of the financial sector to economic growth, particularly of the non-oil business segment of the economy. A wider range of government debt instruments could be useful in the conduct of monetary policy through open market operations (repos) as well as for a smoother functioning of the inter-bank market. Moreover, their availability across the maturity spectrum is often useful to set reference prices for (and aid in the development of) other debt instruments, such as corporate and agency debt, long-term bank CDs, or mortgagebacked securities. They also help institutional, and possibly individual, investors achieve more efficient portfolios. A well developed government securities market is not necessarily inconsistent with a budget surplus environment. ${ }^{31}$ The government may want to assess steps to develop the market for treasury securities, and establish objectives for size, range of maturities, and liquidity created by active market-makers. Although there is a cost associated with the issuance of government debt, the benefits noted above may also be substantial.

\section{Credit Information Systems}

\section{The recent creation of Ci-Net represents a major step forward in the}

development of credit information systems, and should help to significantly improve the behavior of individual borrowers and reduce credit risks for lenders. All financial institutions (e.g., banks, investment companies, leasing companies, and others) are members of Ci-Net, which shares information on the credit performance of the borrower and his compliance with CBK regulations regarding limits on personal borrowings. Previously, it was not possible for financial institutions to track borrower performance and compliance effectively.

\footnotetext{
${ }^{31}$ Singapore is a notable example of a country where government securities have been issued and used as a catalyst for financial market development, despite the strong fiscal position of the government and the absence of a need for government borrowing from the point of view of budget financing.
} 


\section{Summary Assessment of Compliance of the Basel Core Principles FOR EFFECTIVE BANKING SUPERVISION}

\section{A. General}

1. A joint mission of the International Monetary Fund and the World Bank visited Kuwait in September 2003, as part of the FSAP. The mission's work included conducting an update of the assessment of compliance with the Basel Core Principles for Effective Banking Supervision. The update was based on several sources, including: (i) an assessment of compliance with the Core Principles for Effective Banking Supervision that was completed in March 2000; (ii) laws, supervisory regulations, and directives issued by the CBK; (iii) discussions with CBK supervisors; and (iv) meetings with the senior management of all Kuwaiti banks. The assessment was conducted by Mr. Michael Yuenger (U.S. Office of the Comptroller of the Currency), with the assistance of Mr. Robert Liu (World Bank).

\section{B. Institutional and Macroprudential Setting, Market Structure-Overview}

2. The main features of banking supervision in Kuwait are described in the Central Bank Law. This law gives the CBK full responsibility for banking supervision and grants it powers to issue directives and instructions to regulate banking activities. Although the Banking Law dates to 1968, the legal framework for banking supervision remains reasonably current as the Central Bank Law has been amended to take account of changes in international practices. Recently, the Central Bank Law was amended to bring the Islamic banks formally under the jurisdiction of CBK, effective December 2003. Subsequently, the CBK announced that it would initially limit the number of Islamic bank licenses that it will issue to one existing institution and two additional applicants. This action was taken to promote a competitive environment for Islamic banks and to allow the CBK to evaluate and refine its supervisory policies and instructions in this area.

3. The structure of the banking system is not complex, with a mixed government and private sector ownership, but predominantly private sector. There are six commercial banks, three specialized banks, one of which operates under Islamic law, and one branch of a foreign bank. The assets of the commercial banking system in Kuwait, including the Islamic bank, totaled KD18.8 billion as of September 30, 2003. Through the Kuwaiti Investment Authority, the government holds controlling interests in two major banks. Most of the remaining banks are privately owned and usually controlled by a related group of shareholders, with the exception of one bank whose shares are more widely held. The banking sector is concentrated, with the two largest banks accounting for more than half of the local banks' total assets, loans and deposits.

4. The banking system appears sound, with an average capital adequacy ratio estimated to be 19 percent. Profits in 2003 have increased over 2002, and asset quality has improved, with non-performing assets declining from 9.9 percent of total loans at December 31, 2000 to 5.4 percent at March 31, 2003. Total provisioning has increased and currently represents approximately 91 percent of NPLs. 


\section{General Preconditions for Effective Banking Supervision}

5. The banking sector is well regulated and supervised. The CBK law provides CBK with extensive powers to issue instructions, both of a general and specific nature. The CBK has a variety of administrative powers to address problems in banks. These powers can range from a simple warning to the removal of the bank from the Bank Register (with the approval of the MoFE). Different measures are used depending on the issue and severity of the problems. However, the CBK lacks a written comprehensive troubled bank resolution framework, including a prompt corrective action program that could be used to promote awareness and enhance transparency in the intervention of troubled banks.

6. In Kuwait, pursuant to regulations of the MoCI, all accounting and reporting for corporate entities, including banks, is subject to IAS, developed by the IAS Committee. The IAS also governs disclosure rules. The Stock Exchange prescribes additional disclosure standards for listed companies. Banks, and other companies, are required to have two independent external auditors, who work individually to perform the audit function under internationally accepted audit standards.

7. The laws underpinning Kuwait's financial and commercial sectors could be improved to bring them in line with modern international corporate practice, especially the laws governing the operation of companies (Law on Commercial Companies, No. 15 of 1960) and bankruptcy (Law of Commerce, No. 68 of 1980). During the Souk Al-Manakh crisis and the Iraqi invasion and occupation, the $\mathrm{CBK}$ and the government supported the entire banking system and no bank was allowed to fail. The effectiveness of the bankruptcy law for closing banks has, therefore, not been tested because to date, no bank in Kuwait has been closed or had its license revoked.

8. There is no formal deposit insurance system in Kuwait. In order to restore confidence and provide financial market stability in the aftermath of the 1980s stock market crisis and the Iraqi invasion, the government has provided an implicit guarantee that it will protect the accounts of all depositors except inter-bank deposits. Since the guarantee increases moral hazard, reduces market discipline, and could prove costly, the government intends to remove the guarantee in the near future. The authorities believe that the effects of eliminating the guarantee will be manageable and not seriously disruptive. The authorities do not plan to implement a deposit insurance scheme when the guarantee is removed.

\section{Main Findings}

9. Under the CBK Law, the CBK is responsible for the supervision and regulation of deposit and non deposit-taking financial institutions in Kuwait. These include banks, investment companies, exchange houses, and investment funds. In the law, there is some sharing of authority over certain aspects of supervision with the MoFE, but in practice, the bank supervisory actions are mostly taken based on determinations by the CBK. Nevertheless, it would be desirable to amend the CBK Law to further enhance the independence of the CBK in its capacity as banking regulator and supervisor.

10. The Bank Supervision Department (BSD), a unit of the CBK, conducts the on-site inspection and off-site monitoring of individual banks, based on an eighteen-month 
supervisory plan. The CBK has budget independence within the government, but the budget must be approved by the National Assembly (parliament).

The following is a summary evaluation of the 25 Basel Core Principles under the following headings:

\section{Objectives, Autonomy, Powers, and Resources (CP-1)}

11. The Banking Law grants the CBK the authority and responsibility to supervise banks, including licensing, supervision, and inspection of all institutions. The Central Bank has the power to establish and enforce prudential safety and soundness standards and regulations. To accomplish these goals, the BSD has about 140 professional and support staff to carry out its supervisory activities.

12. The independence of the CBK's supervisory authority is fairly well established, although the involvement of the MoFE in the CBK's decisions on licensing, closure, and certain administrative actions could compromise the operational independence of the CBK in implementing its supervisory policies and actions. CBK supervisors are not provided specific legal protection in the exercise of their duties. Instead, the protection is provided under the general service laws that are applicable to all government employees. Lastly, the significant deficiency in the ongoing operations of Kuwait's bank supervision program is the legal prohibition on $\mathrm{CBK}$ from sharing confidential supervisory information with appropriate governmental and foreign supervisory authorities.

\section{Licensing and Structure (CPs 2-5)}

13. The Central Bank Law explicitly identifies banking as a regulated activity. A bank cannot legally commence business until it is registered in the Register of Banks of the CBK. A recent amendment to the Banking law formally brings the Islamic banks under the CBK jurisdiction, beginning December 2003.

14. Although the CBK has established criteria for licensing of banks, including the minimum qualification required for directors and senior management, the licensing and supervisory process is deficient with respect to ownership issues. The banking supervisors lack the authority to determine the suitability of controlling shareholders for proposed new banks or the proposed acquisition of controlling shareholder interests in established banks. Kuwaiti corporate law, which governs the ownership issue, permits Kuwaiti corporations, groups or individuals to acquire controlling interests in Kuwaiti corporations, including banks without any prior regulatory approval. This is a major impediment to the CBK's prudential oversight authority and its ability to supervise banks and related companies on a consolidated basis.

15. The supervisory authority has the authority to review and approve significant acquisitions by banks, taking into account the risks involved for the bank and public interests. The approval process is designed to allow the supervisors to judge each proposed acquisition and its impact on the bank based on the specifics of the proposal. However, there are no established comprehensive benchmarks or standards by which every proposal must be measured. This does not promote transparency or assure objectivity in the approval process. 


\section{Prudential Requirements (CPs 6-15)}

16. The Central Bank's prudential regulations and requirements for banks are generally sound, but a few aspects should be strengthened in order to reach full compliance with all the BCPs. The minimum capital requirements for all Kuwaiti banks are above the minimum set by the Basel Capital Accord.

17. The supervisory standards for credit policies, loan evaluation and loan loss provisioning, large exposure limits, connected lending, and country risk are generally consistent with the BCP. The classification of accounts is based on delinquency status and not on loan quality. A minimum general provisioning of 2 percent is required on all performing credits to compensate for this weakness in loan classification methodology. Although there are limitations on connected party lending, the word "connected parties" is too narrowly defined to prevent abuse. It should be broadened to include affiliates and/or parties that are related to directors and senior management through common ownership.

18. The CBK's approach to the supervision of country, market, and other risks is broadly in line with international standards. Most Kuwaiti banks have only nominal market risk due to limited products offered. The external auditors play an important role in the governance process and in the independent oversight function. The CBK rules require external auditors to provide a written report to the supervisors when a qualified opinion is expressed in the financial statements. The external auditors are also required to meet with the bank supervisors to discuss their reasons for issuing a qualified opinion.

19. The CBK recently issued revised anti-money laundering guidelines to local banks. Although these guidelines are broadly in line with good international practices, weaknesses remain in Kuwait's overall framework for AML.

\section{Methods of Ongoing Supervision (CPs 16-20)}

20. Both on-site inspection and off-site supervision of banks are performed. The CBK reports that it has developed examination procedures to cover Islamic banking institutions and their products when the Islamic banks become subject to CBK supervision in December 2003. The supervisory activities assure regular contact between supervisors and banks.

21. The CBK receives appropriate monthly and quarterly reports from banks. The frequency can be increased if there are any concerns. The supervisory information is validated through on-site work and through the use of external auditors.

22. Consolidated supervision in Kuwait has been limited because CBK lacks the legal authority to approve changes in the ownership control of banks, including requesting corporate information, and cannot share information with other governmental authorities and foreign host country supervisory authorities. This limitation on accessing corporate information restricts the supervisor from evaluating the risks associated with the non-banking activities of the group. 


\section{Information Requirement (CP-21)}

23. Banks, as well as other corporations in Kuwait, are required to prepare financial statements and various reports in accordance with the IAS. The KSE requires listed banks to publish financial statements signed by their external auditors on a quarterly basis.

\section{Formal Powers of Supervisors (CP-22)}

24. The CBK law provides the supervisors with a range of supervisory measures to address a bank's failure to meet regulatory requirements. These measures include a warning, a reduction or suspension of credit granted to it, limitation of certain operations, appointment of a controller, and deletion from the Register of Banks. They are limited in scope and are not based on predefined, explicit criteria such as the prompt corrective action measures. Pending legislation, if enacted, would expand the range of corrective measures available to the CBK. These include removing the board members and appointing a commissioner to manage the bank on an interim basis. The proposed powers would permit the CBK Board to act without requiring the prior approval of the MoFE.

\section{Cross Border Banking (CP 23-25)}

25. The CBK has the authority to supervise the overseas activities of locally incorporated banks. Kuwaiti banks that want to establish overseas branches must obtain the CBK's prior approval. While several Kuwaiti banks have overseas branches, there is only one branch of a foreign bank operating in Kuwait, reflecting the restriction on foreign ownership.

26. Owing to secrecy provisions in the banking law, information sharing with home and host country supervisory authorities is virtually impossible. This major weakness in the supervisory process will be corrected if the legislation currently pending in the National Assembly is enacted. The amendment would provide CBK with the authority to share supervisory information with foreign supervisors. To prepare for this change, the CBK should start working on draft copies of MOUs that would be exchanged with other foreign supervisors. 
27. The following table summarizes the principal recommendations and priorities:

\begin{tabular}{|c|c|}
\hline Reference Principle & Recommended Action \\
\hline $\begin{array}{l}\text { CP1.2 Objectives, Autonomy, Powers and } \\
\text { Resources }\end{array}$ & $\begin{array}{l}\text { - Adopt legislative changes that would remove } \\
\text { MoFE influence over CBK decisions on } \\
\text { licensing, closure, and certain other remedial } \\
\text { actions. } \\
\text { The Central Bank Law should be amended to } \\
\text { allow for sharing of supervisory information } \\
\text { between domestic regulators and between } \\
\text { domestic and foreign banking supervisors. }\end{array}$ \\
\hline $\begin{array}{l}\text { CP3 Licensing Criteria } \\
\text { CP4 Ownership }\end{array}$ & $\begin{array}{l}\text { - The banking supervisors should be given the } \\
\text { authority to reject applications for banking } \\
\text { licenses when the owners do not meet the "fit } \\
\text { and proper" test. }\end{array}$ \\
\hline CP10 Connected Lending & $\begin{array}{l}\text { - The definition of connected lending should be } \\
\text { expanded to include affiliates and related } \\
\text { parties that are connected to the director's } \\
\text { interest through common ownership. }\end{array}$ \\
\hline CP22 Remedial Measures & $\begin{array}{l}\text { - The authorities should consider establishing a } \\
\text { graduated formal framework for dealing with } \\
\text { problem banks, and this framework should be } \\
\text { transparent so as to allow the various } \\
\text { stakeholders to know CBK requirements for } \\
\text { maintaining a banking license. }\end{array}$ \\
\hline $\begin{array}{l}\text { CP24 Host Country Supervision } \\
\text { CP25 Supervision over Foreign Banks' } \\
\text { Establishment }\end{array}$ & $\begin{array}{l}\text { - Approve legislation in the National Assembly } \\
\text { allowing the supervisory authorities to share } \\
\text { confidential information with domestic } \\
\text { regulators and foreign supervisors. Following } \\
\text { enactment of the legislation, the supervisory } \\
\text { authorities should enter into MOUs with } \\
\text { domestic and foreign counterparts for sharing } \\
\text { of confidential information. }\end{array}$ \\
\hline
\end{tabular}

\section{E. Authorities' Response}

28. The authorities generally welcomed the assessment and are evaluating its suggestions for strengthening the existing supervisory regime. They noted that pending legislation in the National Assembly, including proposed amendments to the CBK Law, would address the deficiencies relating to information sharing, share transfers involving ownership changes, consolidated supervision, and international cooperation. Translations of draft legislation shared with the assessor tend to support the view that the proposed measures would further strengthen an already broadly sound supervisory regime. However, the authorities agreed that the draft legislation remains to be enacted and implemented before the effectiveness of such measures can be evaluated against the Basel Core Principles. 


\section{IOSCO ObJectives ANd Principles of Securities Regulation}

\section{A. General}

29. The assessment of the securities regulatory system in Kuwait was performed as part of the FSAP assessment for Kuwait in July and September 2003. The assessment is of the legislative and regulatory frameworks, the operations of the regulating agency, the stock exchange and the trading, clearing, settlement and other operational systems, as well as market intermediaries. The assessment aims to determine the extent of observance of the IOSCO Principles and to suggest areas where measures may be appropriate.

30. The assessment is based on a review of laws, rules and regulations, interviews (with government officials, the KSE management and staff, legal experts, representatives of the securities industry, and some investors), a self-assessment report prepared by the KSE, additional reference materials, and other publicly available information. The Kuwaiti authorities cooperated fully with the assessment, which was conducted by Ashraf Shamseldin, IMF Securities Advisor, in July and September 2003.

\section{B. Information and Methodology Used for the Assessment}

31. The assessment is based on the methodology developed by IOSCO (as revised in April 2003).

32. The securities market in Kuwait is regulated by several agencies and is governed by the securities market Amiri Decree-Law of 1983. The MC and KSE are responsible for the supervision of the securities secondary market, while the CBK supervises investment companies. The $\mathrm{CD}$ of the MoCI supervises the primary securities market (the issuers).

33. The securities markets are beginning to play a role, albeit still marginal, as a source of medium- and long-term finance. The primary market is not active, and basic financial intermediation services are lacking. The bulk of secondary market is in equities.

34. There are few institutional investors, and individual investors exhibit speculative behavior. Institutional investment is mainly passive and has not spurred the development of a broader range of financial instruments and techniques.

35. The securities industry is thin, with non-diversified and small intermediary firms. At the end of 2002, there were 13 licensed brokerage firms and 71 investment companies (comprising 33 investment funds and 38 conventional and Islamic investment companies). Standards for market entry and prudential pre-requisites for licensing are not sufficient.

36. The KSE is the only national stock exchange in Kuwait. It is a government entity and operates as a cash market. A parallel system was introduced in 1998 for forward trading, although activity in this market remains limited. At the moment, no derivatives are traded in the Kuwaiti market. In 1988, investment barriers were removed for the citizens of GCC countries, who were permitted to trade on the KSE. In August 2000, the market was opened to all foreign investors, and especially Arab countries. 
37. Equity and debt trades on the KSE are cleared and settled through the KCC, which also acts as the securities depository and registry. Banks provide custodial services for non-Kuwaiti investment. Under the system developed by the $\mathrm{KCC}$, securities are immobilized and not dematerialized.

\section{General Preconditions for Effective Securities Regulation}

38. The regulatory environment for the securities market in Kuwait generally does not conform to the preconditions in the IOSCO Objectives and Principles. The developmental aspects of the securities market are neglected. The level of authority and power delegated to the regulating agency does not correspond to its responsibilities. Other essential legal aspects, notably the protection of minority shareholders, and the prohibition of market manipulation and insider trading, are also missing in present laws.

\section{Main Findings}

39. While modest progress has been made in the recent past towards strengthening the regulatory and institutional aspects of securities market supervision, substantial further improvement is needed. Attention needs to be given to systematizing the many regulations and circulars issued in recent years. Market participants and investors cannot keep abreast of the rules and regulations for compliance purposes.

40. Although the law establishes broad mandates for the supervision of the intermediaries in the securities market, the lack of an orderly regulatory framework has led to a significant fragmentation of responsibilities. From a statutory viewpoint, the MC is an independent agency, although in practice it is not. The government appoints the director-general and the majority of the board of directors. The MC has only limited powers to fulfill its mandate, as most licensing, supervision, and sanction powers lie elsewhere. The inspection, investigation, and surveillance powers of the MC and KSE are not adequate and lack a clear process. The power to set technical standards for the market is fragmented and not well coordinated. In addition, the staffing of the $\mathrm{MC}$ and $\mathrm{KSE}$ needs strengthening to increase efficiency.

41. While information sharing and coordination with other regulators is legally permitted, there is no formal protocol for cooperation with foreign agencies and among national regulatory and supervisory agencies. This is of particular concern now that the market is open to foreign investors.

42. The design of the clearing and settlement system largely prevents payment default. However, the dematerialization of securities cannot be properly implemented in the absence of the necessary legal basis.

43. Licensing requirements for market intermediaries are few and broad. With the exception of brokers, who are supervised by KSE, other intermediaries are regulated by different agencies. The term "Investment Company" is not clearly defined. Regulations related to intermediaries and intermediation are inadequate. 


\section{E. Summary of Principles Assessment}

- Strength of the regulator. The securities market is regulated by more than one agency. Division of responsibility between them risks inefficiencies and gaps. The various laws and regulations that govern the market do not form a comprehensive legal framework. The power and jurisdiction of the MC is limited and confined only to the stock exchange and member brokers. The KSE is not, in practice, operationally independent of external political or commercial interference in the exercise of its regulatory and supervisory functions. The sanctioning system is insufficient to maintain market order. The rule-making process is not clear. There is no consolidated master reference for rules and executive decisions for easy reference by the different users. The regulatory agencies often do not consult with industry and the public. No comprehensive inspection procedure, or a plan for such, is in place, and inspections are not regularly performed. Insider trading is not prohibited and consequently not penalized. Lastly, information sharing procedures have not been formalized through MOUs among the relevant agencies.

- $\quad$ Self regulatory organizations (SROs). Although the KSE may exercise a few functions of an SRO, effective self-regulation is not practiced. As the market gains maturity and experience, sound SRO principles can be more fully implemented. Legal changes would be needed to clarify the manner in which SROs are to complement regulation.

- Issuer regulation. Regulations and procedures for public offerings of securities including tender offers are not adequate. The responsibilities of regulators for the control of public as well as private offerings, sale, and distribution of securities need to be more clearly defined. Rules governing mergers and acquisitions are not in place. Corporate governance principles have not been fully addressed. There is need to strengthen minority shareholders' protection. In addition, a list of eligible auditors is needed to ensure the quality of the auditing, particularly of financial intermediaries and listed companies.

- Investment fund regulation. Regulation and supervision of CISs are segmented among three agencies. Fit and proper assessments are not sufficiently strong. Rules and regulations for the protection of investors are needed and should be strictly enforced. In addition, guidelines and prudential rules regarding funds' investment policy are inadequate, as is their enforcement.

- $\quad$ Market intermediary regulation. Entry standards for market intermediaries need to be established for each type of service. Prudential rules and regulations need to be in place for all types of intermediaries from incorporation to liquidation. Licensing and inspection of intermediaries need to be the responsibility of one regulatory agency. These rules and regulations need to be supplemented by a code of ethics for each type of intermediary. Any company rendering intermediary service should be required to establish clear internal procedures in full compliance with rules and regulations. 
Criteria for capital adequacy and solvency should be established and closely supervised and monitored by the regulating agency.

- $\quad$ Secondary market regulation. The MC and the KSE are not fully separate institutions, each with its own resources and staff. The present arrangement does not adequately avoid conflict of powers, mandates, interests, and functions. The nonprohibition of insider trading is a serious defect, making it difficult for the KSE to maintain the fairness and integrity of the market. Systems to deter and detect unlawful and fraudulent practices are weak. The KSE does not have sufficient ability to impose sanctions, including fines. The lack of ultimate dematerialization and automated book entry raises risks. While the $\mathrm{KSE}$ is authorized to supervise the $\mathrm{KCC}$, no formalized system of supervision is in place.

44. These findings give rise to the following recommended actions. The priorities are to: create an independent and accountable authority with full powers to develop and regulate the securities market and industry; prohibit insider trading and market manipulation; establish adequate enforcement powers; and define entry standards for all types of market intermediaries.

\begin{tabular}{|c|c|}
\hline Reference Principle & Recommended Action \\
\hline $\begin{array}{l}\text { Principles Relating to the } \\
\text { Regulator }\end{array}$ & $\begin{array}{l}\text { - The objectives, functions, responsibilities, and } \\
\text { powers of the securities market regulator should } \\
\text { be clearly defined by a comprehensive and unified } \\
\text { law, to be formulated in line with the basic } \\
\text { principles regarding the objectives that the } \\
\text { regulator should meet: (1) protection of investors; } \\
\text { (2) assurance that markets are fair, efficient and } \\
\text { transparent; and (3) reduction of systemic risk. } \\
\text { The law should give the regulator full, } \\
\text { comprehensive, and overall power to develop, } \\
\text { organize and regulate the securities market and } \\
\text { industry, and to set rules and enforce them in } \\
\text { consultation with market participants and the } \\
\text { public. } \\
\text { The law should create an independent and } \\
\text { accountable authority with clear organizational } \\
\text { structure. Independence, in terms of resources and } \\
\text { ability to take final and enforceable decisions, } \\
\text { needs to be clearly defined by law. In addition, the } \\
\text { regulator should develop a wide spectrum of } \\
\text { sanctions including cash fines, and be empowered } \\
\text { to impose these sanctions. }\end{array}$ \\
\hline $\begin{array}{l}\text { Principles for the Enforcement of Securities } \\
\text { Regulation }\end{array}$ & $\begin{array}{l}\text { - Insider trading and market manipulation should be } \\
\text { prohibited, and a set of rules and instructions } \\
\text { regarding observance of confidentiality needs to be } \\
\text { established and supplemented by an explicit code } \\
\text { of ethics applied to regulatory personnel. } \\
\text { - The regulator should be empowered to regulate and } \\
\text { oversee the primary market, including the IPO and }\end{array}$ \\
\hline
\end{tabular}




\begin{tabular}{|c|c|}
\hline & $\begin{array}{l}\text { PO processes and the issuance of rules and } \\
\text { regulations. Its powers should include the adoption } \\
\text { of specific accounting requirements for disclosure } \\
\text { regarding the public offering of securities, tender } \\
\text { offers, as well as mergers and acquisitions. } \\
\text { - The regulator should set rules for the protection of } \\
\text { minority shareholders and compel listed companies } \\
\text { to implement principles of corporate governance. } \\
\text { The regulator should build enough capacity to } \\
\text { examine compliance of auditors and audited } \\
\text { companies with accounting and auditing standards } \\
\text { as well as other disclosure requirements. The } \\
\text { regulator should arrange for the conduct of } \\
\text { continuous training programs for its staff. } \\
\text { Entry standards for all types of market } \\
\text { intermediaries should be established and } \\
\text { complemented with prudential regulations } \\
\text { governing their licensing, supervision and } \\
\text { sanctioning. Owners and officers of licensed } \\
\text { intermediaries should be subject to fit and proper } \\
\text { conditions to be developed by the regulator. The } \\
\text { regulator should be empowered to inspect the } \\
\text { books, records and business operations of licensed } \\
\text { intermediaries. It should be empowered to impose } \\
\text { necessary and relevant sanctions that would } \\
\text { provide full protection to clients. }\end{array}$ \\
\hline Principles for Cooperation in Regulation & $\begin{array}{l}\text { Pending the amendment of the current legal } \\
\text { framework, present supervisory agencies should } \\
\text { formalize a procedure for consultation and the } \\
\text { exchange of information, and combine inspection } \\
\text { and investigation efforts. Similar arrangements } \\
\text { should be made for international cooperation. }\end{array}$ \\
\hline
\end{tabular}

\section{F. Authorities' Response}

The assessment has been discussed with the responsible authorities, who have broadly agreed with the findings. The authorities have already begun to formulate plans to improve the regulation and supervision of the securities sector. 


\section{REPORT ON OBSERVANCE OF STANDARDS AND CODES \\ FATF RECOMMENDATIONS FOR ANTI-MONEY LAUNDERING AND COMBATING THE FINANCING OF TERRORISM}

\section{A. Introduction}

45. This Report on the Observance of Standards and Codes for the FATF 40 Recommendations for Anti-Money Laundering and 8 Special Recommendations for Combating the Financing of Terrorism was prepared by Mr. Richard Chalmers (MFD), Ms. Joy Smallwood (LEG), and an expert not under the supervision of Fund staff who was selected from a roster of experts in the assessment of criminal law enforcement activities (Ms. Susan Smith, U.S. Department of Justice). The report provides a summary of the level of observance of the FATF 40+8 Recommendations, and provides recommendations to strengthen observance.

\section{B. Information and Methodology Used for the Assessment}

46. In preparing the detailed assessment, Fund staff reviewed the relevant AML/CFT laws and regulations, and supervisory and regulatory systems in place to deter money laundering and financing of terrorism among prudentially regulated financial institutions, which, in Kuwait, include the exchange and remittance companies. Staff also considered the measures to oversee the gold market, which is macro-economically relevant, and charitable organizations, which are significant features of the Kuwaiti society. The expert not under the supervision of Fund staff reviewed the capacity and implementation of criminal law enforcement systems. ${ }^{32}$ The assessment is based on the information available at the time it was completed in midOctober, 2003.

\section{Main Findings}

47. By comparison with many financial centers, Kuwait's vulnerability to money laundering may be considered relatively low. The banking and investment services sectors are largely directed towards servicing domestic clients drawn from a small indigenous population, and the system does not operate as a conduit for significant transit flows of funds in and out of the country. However, there are some vulnerabilities in the system. The absence of key controls in the fast-growing stock market, such as the outlawing of insider dealing and market manipulation, may provide an added incentive to abuse of this market. The gold market is also a prominent feature of the wider financial landscape, but it is of such a disparate retail nature that effective AML regulation presents particular challenges. The financing of terrorism has not been criminalized, but the authorities have taken measures to regulate the activities of the charitable organizations.

${ }^{32}$ The text in this report attributed to the independent law enforcement expert is shown in italics. 


\section{Criminal Justice Measures and International Cooperation}

\section{Criminalization of money laundering and financing of terrorism}

48. Law 35/2002, combined with the implementation of subsidiary rules by the regulators, provides the legal basis for countering money laundering. Currently, only banks, investment companies, money exchange operators, and insurance agencies are covered by the law, as the intended "umbrella" resolution to extend it to the wider market has not yet been issued by the Minister of Finance. While the primary legislation is general in nature, the detailed implementing instructions issued by the CBK for banks and exchange houses have closely followed international standards.

49. Kuwait has not ratified either the Palermo Convention or the 1999 Suppression of the Financing of Terrorism Convention, and has no specific CFT legislation. Some authorities believe that terrorist financing is covered directly in Law 35/2002 and have issued their regulations on this basis, while others suggest that the issue is addressed through the use of provisions within the criminal law. Neither of these suggestions appears firmly based.

\section{Confiscation of proceeds of crime or property used to finance terrorism}

50. There are no specific provisions for the freezing, restraint and forfeiture of assets associated with terrorist financing. The authorities must rely on general provisions of the Penal Code and on a statute that makes it illegal to establish a society or group that engages in illegal acts. There must be doubts about the effectiveness of using these provisions in relation to the financing of terrorism.

\section{The FIU and processes for receiving, analyzing, and disseminating intelligence at the domestic and international levels}

51. The FIU is part of the CBK and has no distinct organizational structure. While it receives its basic authority from the Governor of the $\mathrm{CBK}$, its powers to receive, analyze and investigate STRs are derived solely from the powers extended to it from the PPO on a case-bycase basis. This leads to inefficiency in its operations. Further, the FIU has an extremely limited ability to share information with its foreign counterparts.

52. The standard for filing STRs is not mere suspicion, but rather a reasonable belief that money laundering has occurred. This has limited the numbers of STRs filed, and has placed an undue burden on the banks to act as investigators, in which capacity they routinely risk "tipping off" the customer. The two-day period specified under the regulations for the freezing of transactions during an investigation is rarely sufficient, resulting in the banks surreptitiously extending the freeze, placing them at risk of civil action.

\section{Law enforcement and prosecution authorities, powers and duties}

53. The PPO has the responsibility for investigating and prosecuting money laundering cases. It has extremely wide powers to investigate crimes and can obtain bank or other records by means of a simple letter request. The PPO and Ministry of Interior's Criminal Investigation Division (CID) work closely on all criminal cases. Law enforcement techniques 
such as undercover operations, controlled delivery, use of informants, and wire-tapping are permitted with the PPO's approval or when authorized by the court, although they have not yet been used in the investigation of money laundering.

\section{International cooperation}

54. Law 35/2002 creates a mechanism for providing mutual legal assistance in money laundering investigations or prosecutions when there is a multilateral agreement or bilateral treaty. While Kuwait has entered into some treaties, its ability to provide timely and effective assistance is hampered by the requirement that assistance can only be given when a request comes from a "competent judicial authority." Only in very rare circumstances will a prosecutor's office be such an authority, and thus most countries will be required to use "letters rogatory," a process that is generally very slow.

55. Regulatory co-operation at both the domestic and international level is severely restricted by statutory secrecy provisions. Amendments to the CBK law to introduce information-sharing provisions are currently before the parliament, but these will not extend to the other regulatory authorities in Kuwait.

\section{E. Preventive Measures for Financial Institutions}

56. The CBK is charged with the prudential supervision of the banks, investment companies, exchange companies and mutual funds. The MoCI has similar responsibilities for the insurance sector, oversees the gold market and regulates the securities market together with the KSE.

\section{Prudentially-regulated sectors}

57. An Islamic bank, the second largest financial institution in Kuwait, is currently not under the same regulatory regime as the other banks. Legislation to correct this comes into force in December 2003, after which the bank in question will have six months in which to register as a bank. While the bank in question has indicated that it has already voluntarily followed the CBK's AML instructions, there has been no independent verification, since the CBK currently has no right of access to the bank's operations.

58. There are no controls over the ownership of any regulated financial institutions, and the CBK only has powers to apply "fit and proper" tests to the management of banks. Amendments are before parliament to address the issue of ownership with respect to the banking sector, but not more generally.

59. The CBK's AML instructions to the banks are generally soundly based and closely mirror international standards. The CBK has applied a systematic process, supported by written procedures, to check compliance with its requirements, but no revised instructions have yet been issued to the investment companies, which continue to follow regulations issued in 1993. Instructions issued by the CBK to the licensed exchange companies impose customer identification requirements similar to those applicable to the banks, and measures have been implemented to control large cash remittances overseas through this sector. The KSE has issued a resolution on AML/CFT which could be strengthened. 


\section{Non-prudentially-regulated sectors}

60. The authorities have taken a robust approach to overseeing the activities of the charitable organizations. This is reflected in the licensing arrangements for individual projects; the outlawing of cash contributions (leading to the requirement for all donations to be put through the banking system); the introduction of audit requirements; and the proposals to use the Kuwaiti embassies abroad to monitor the use of the funds in the recipient projects.

61. Customer identification and record keeping requirements were extended to the gold market by Ministerial Order in 2002. However, there is a general lack of application of the obligations within this sector, apparently stemming from a lack of awareness of the requirements.

\section{F. Summary Assessment against the FATF Recommendations}

62. The enactment of AML legislation in 2002, supported by regulations issued by the authorities, has provided a basis for compliance with several of the Recommendations. However, the failure specifically to criminalize the financing of terrorism, and the uncertainty about the effectiveness of alternative mechanisms to prosecute such cases, is detrimental. In addition, the current structure of the FIU, the exceptionally high burden of evidence for filing STRs, and the legal constraints on international cooperation currently present obstacles to compliance with many important Recommendations.

63. The recommended actions below reflect this assessment. Key priorities are to: ensure that AML legislation covers the broad financial sector; exercise more control over ownership of financial institutions; strengthen procedures for international cooperation in AML/CFT; and criminalize the financing of terrorism.

\begin{tabular}{|c|c|}
\hline Reference FATF Recommendation & Recommended Action \\
\hline \multicolumn{2}{|l|}{40 Recommendations for AML } \\
\hline $\begin{array}{l}\text { General framework of the Recommendations } \\
\text { (FATF 1-3) }\end{array}$ & $\begin{array}{l}\text { - Introduce provisions within all the regulatory } \\
\text { laws to permit the authorities to exchange } \\
\text { information with both domestic and foreign } \\
\text { counterparts. } \\
\text { Enact legislation allowing mutual legal assistance } \\
\text { with non-judicial authorities, including assistance } \\
\text { in confiscation matters. }\end{array}$ \\
\hline \multicolumn{2}{|l|}{$\begin{array}{l}\text { Scope of the criminal offense of money laundering } \\
\text { (FATF 4-6) }\end{array}$} \\
\hline \multicolumn{2}{|l|}{ Provisional measures and confiscation (FATF 7) } \\
\hline $\begin{array}{l}\text { General role of financial system in combating ML } \\
\text { (FATF 8-9) }\end{array}$ & $\begin{array}{l}\text { Introduce AML regulations for investment } \\
\text { companies. } \\
\text { Issue the Ministerial Order to extend the coverage } \\
\text { of Law } 35 / 2002 \text { to all relevant institutions. }\end{array}$ \\
\hline $\begin{array}{l}\text { Customer identification and record-keeping rules } \\
\text { (FATF 10-13) }\end{array}$ & $\begin{array}{l}\text { Extend the CBK's instructions: (i) to address risk } \\
\text { variables in the customer identification process; } \\
\text { (ii) to confirm the current operational practice on } \\
\text { acceptance of introduced business; and (iii) to }\end{array}$ \\
\hline
\end{tabular}




\begin{tabular}{|c|c|}
\hline & $\begin{array}{l}\text { require the identification of significant } \\
\text { shareholders of corporates. }\end{array}$ \\
\hline $\begin{array}{l}\text { Increased diligence of financial institutions (FATF 14- } \\
\text { 19) }\end{array}$ & $\begin{array}{l}\text { Review the procedures for filing STRs to lower } \\
\text { the level of suspicion required to trigger a report, } \\
\text { and to guard against inadvertent tipping-off. } \\
\text { Require all financial institutions to have a specific } \\
\text { AML/CFT compliance function. }\end{array}$ \\
\hline $\begin{array}{l}\text { Measures to cope with countries with insufficient } \\
\text { AML measures (FATF 20-21) }\end{array}$ & $\begin{array}{l}\text { - Provide guidance on the jurisdictions in relation } \\
\text { to which financial institutions should take special } \\
\text { care. }\end{array}$ \\
\hline \multicolumn{2}{|l|}{ Other measures (FATF 22-25) } \\
\hline $\begin{array}{l}\text { Implementation \& role of regulatory and other } \\
\text { administrative authorities (FATF 26-29) }\end{array}$ & $\begin{array}{l}\text { - Publish guidance by the FIU to assist financial } \\
\text { institutions to understand their broad obligations } \\
\text { under the STR regime and the processes to be } \\
\text { followed. } \\
\text { Introduce statutory controls to ensure that all } \\
\text { significant shareholders and owners, and all } \\
\text { directors and management staff of all financial } \\
\text { institutions are subject to "fit and proper" tests by } \\
\text { the regulators. }\end{array}$ \\
\hline \multicolumn{2}{|l|}{$\begin{array}{l}\text { Administrative Cooperation-Exchange of general } \\
\text { information (FATF 30-31) }\end{array}$} \\
\hline $\begin{array}{l}\text { Administrative Cooperation-Exchange of } \\
\text { information relating to suspicious transactions } \\
\text { (FATF 32) }\end{array}$ & $\begin{array}{l}\text { Enact legislation to permit the FIU to request } \\
\text { from, and share information spontaneously with, } \\
\text { its foreign counterparts through administrative } \\
\text { procedures. }\end{array}$ \\
\hline \multicolumn{2}{|l|}{$\begin{array}{l}\text { Other forms of cooperation-Basis \& means of } \\
\text { cooperation in confiscation, mutual assistance, and } \\
\text { extradition (FATF 33-35) }\end{array}$} \\
\hline $\begin{array}{l}\text { Other forms of cooperation-Focus of improved } \\
\text { mutual assistance on money laundering issues (FATF } \\
36-40 \text { ) }\end{array}$ & $\begin{array}{l}\text { Enact appropriate laws and procedures to provide } \\
\text { the widest possible range of mutual legal } \\
\text { assistance in AML/CFT matters in a timely } \\
\text { fashion. }\end{array}$ \\
\hline \multicolumn{2}{|l|}{8 Special recommendations on terrorist financing } \\
\hline I. Ratification and implementation of UN Instruments & $\begin{array}{l}\text { - Ratify and implement the Palermo Convention } \\
\text { and the } 1999 \text { Convention on Suppression of the } \\
\text { Financing of Terrorism. }\end{array}$ \\
\hline $\begin{array}{l}\text { II. Criminalizing the financing of terrorism and } \\
\text { associated money laundering }\end{array}$ & - Enact legislation to criminalize terrorist financing. \\
\hline III. Freezing and confiscating terrorist assets & $\begin{array}{l}\text { - Enact legislation to provide for the identification, } \\
\text { freezing, seizure, and confiscation of terrorist } \\
\text { assets. }\end{array}$ \\
\hline $\begin{array}{l}\text { IV. Reporting suspicious transactions related to } \\
\text { terrorism }\end{array}$ & $\begin{array}{l}\text { Enact legislation to criminalize terrorist financing, } \\
\text { thereby making it a predicate offense for } \\
\text { reporting. }\end{array}$ \\
\hline V. International Cooperation & - $\quad$ As for FATF 36-40 above. \\
\hline \multicolumn{2}{|l|}{ VI. Alternative remittance } \\
\hline VII. Wire transfers & $\begin{array}{l}\text { - Issue instructions to the banks on the handling of } \\
\text { incoming wire transfers. }\end{array}$ \\
\hline VIII. Non-profit organizations & \\
\hline
\end{tabular}


Other Recommended Actions

\begin{tabular}{|l|l|}
\hline \multicolumn{1}{|c|}{ Reference } & \multicolumn{1}{c|}{ Recommended Action } \\
\hline & $\begin{array}{l}\text { Enact new legislation to create an independent, } \\
\text { adequately resourced FIU that will receive, } \\
\text { maintain, analyze, and evaluate STRs and } \\
\text { currency reports, and will have the power to co- } \\
\text { operate with foreign counterparts. }\end{array}$ \\
\hline & $\begin{array}{l}\text { Amend Law 35/2002 to include the reporting of } \\
\text { outbound cross border movements of currency, } \\
\text { gold or other precious materials. }\end{array}$ \\
\hline & $\begin{array}{l}\text { Raise awareness of AML obligations among the } \\
\text { gold dealers. }\end{array}$ \\
\hline
\end{tabular}

\section{G. Authorities' Response}

The authorities were in broad agreement with the assessment. Several revisions were made to the detailed assessment in response to their comments on technical matters. 